\title{
CLASSIFICAÇÃO LINGÜÍSTICO-ETNOLÓGICA DAS TRIBOS INDÍGENAS DO PARÁ SETENTRIONAL E ZONAS ADJACENTES 1
}

\author{
Frei Protásio Frike1, O.F.M. \\ (Museu Paraense "Emílio Goeldi", Belém) \\ Plano de Apresentação \\ I - Quadro hidro-geográfico \\ II - Habitat e densidade demográfica \\ III - Divisão lingüístico-cultural \\ IV - Nomes tribais e designações de grupos \\ $\mathrm{V}$ - Classificação esquemática \\ VI - Tribos bravias ou de cultura marginal \\ VII - Registro das tribos
}

\section{I - Quadro hidro-geográfico}

Para se compreender melhor a classificação destas tribos indígenas, é mister esboçar, em traços gerais embora, o quadro da região. Neste esbôço, destacar-se-á de preferência o aspecto hidrográfico da paisagem, porquanto para o índio as condições de alimentação, habitação e migração dependem, sobremodo, dos rios que the fornecem (embora não de modo exclusivo) o peixe, atraem a caça, garantem a fertilidade dos terrenos de plantio e constituem as vias de penetração para o vasto e inexplorado interior.

Comecemos, pois, os sistemas fluviais em aprêço, principalmente c do Trombetas.

O atual Pará Setentrional constitui, por si mesmo, uma zona quase demarcada. Limita-se a oeste pelo rio Nhamundá; a leste, pelo Jari; ao norte, alcança as divisas do Brasil com as Guianas (principalmente a Inglêsa e a Holandesa), divisas estas formadas pelas serras pouco elevadas, mas bastante extensas, do Acaraí e Tumucumaque. Como limite meridional pode-se considerar o Amazonas.

O rio Trombetas, com cêrca de $1.000 \mathrm{~km}$, é o maior afluente da margem esquerda do Amazonas, dentro do Estado do Pará. Com suas inúmeras ramificações, forma enorme rêde de veios dágua que se estende sôbre uma área de aproximadamente 4 graus de latitude e 5 ou 6 de longitude. A bacia do Trombetas, com uma extensão aproximada de 2 graus de latitude sul a 2 graus de latitude norte, e de 54 a 59 
graus ou, respectivamente, a 60 greus de longitude oeste, cobre bem a metade do atual Pará Setentrional.

E' ainda questão pendente se o rio Nhamundá, que limita o Estado do Pará com o do Amazonas, deve ser considerado como rio independente ou como tributário do Trombetas. Sôbre o assunto não existe unanimidade entre os hidrógrafos. A posição singular dêste rio reside no fato de possuir êle duas embocaduras, das quais uma vai ter diretamente ao rio Amazonas e a outra, ao Trombetas, bem defronte da cidade de Oriximiná.

Os rios principais desta área têm suas nascentes nos divisores reais do Acaraí e Tumucumaque (Tumuk-Humak). O mesmo acontece com - próprio Trombetas com seus formadores Cafuíne (Kafuíne, Kafuwíni, Kahú) e Panəmá (Uanamú, Wanamú) e com os seus dois maiores afluentes, o Mapuera e o Erepecuru (ou Cuminá), juntamente com o Marapí. Mas o Trombetas recebe também dos contrafortes e dos divisores de águas secundários (e, portanto, das zonas interfluviais) um número considerável de tributários, que, na parte inferior de seu curso, perto da foz, chegam a ter, às vêzes, 100 ou mais metros de largura.

Seus afluentes mais importantes do lado ocidental são: o já mencionado Mapuera, o Cachorro ou Kachúru, o Yaskurí, o Rio do Velho ou Kuhá e, na sltura equatorial, o Rio Turúnu. A leste recebe o Erepecuru ou Cuminá, o Damiana ou Kah.yáhó, o Kachpakúru, o Imnohúmu e o Ponékuru ${ }^{2}$.

A maioria dêstes rios divide-se, em seu curso superior, em dois ou mais formadores, que para os estudos indigenistas são de alguma importância. Assim, o Mapuera se compõe do Tauíni (Tawíni) e do Urucuriana. Sòmente a partir da confluência dêsses dois formadores é que se dá ao rio a denominação de Mapuera. Cada um dêstes dois últimos, por sua vez, possui como cabeceiras duas ramificçaões maiores: c Tauíni e forma com o Tutúmi e o Kumúnu; o Urucurian尹, com o Eitó e o Moró. Todos êsses rios são habitados por tribos do grupo Parukotó.

Coisa semelhante se dá com o Paru de Oeste, chamado simplesmente Paru pelos Tiriyó, enquanto designam o Paru (Paru de Leste) por Okômôkê. O Paru de Oeste também recebe certo número de afluentes cujas cabeceiras são bastante povoadas de índios. Vindo bem do norte, afluem-lhe pela direita o Kurupíni e, um pouco mais abaixo, o Kumaruwíni, o Karapáwa e o Akahé. Todos êles se originam na grande serra fronteiriça do Tumucumaque. Mais adiante, na zona dos campos, lançam-se nele pela esquerda o Irikí, o Quinze de Novembro e alguns outros de menor importância. Depois da confluência com o Marapí, toma outro nome: Erepecuru ou Cuminá. Em todos êsses rios e igarapés vivem grupos Tiriyó. 
Das regiões interfluviais do Mapuera-Trombetas aflui ao rio principal primeircmente o rio Cachorro. Seu afluente mais importante, o rio Cachorrinho ou Tchôrôáhô, é muito mais extenso que o próprio rio Cachorro e vem das montanhas do Urucuriana-Turúnu. Também o rio Kuhá, que, segundo informações dos índios, se origina de um grande lago central, possui um afluente muito longo, embora estreito, o Kotonúru. Suas margens são ricas em malocas de índios, com os quais, porém, não existe contacto porque são considerados "brevos", "selvagens". Da mesma forma, o vizinho rio Turúnu possui dois formadores, que não conheço de perto, porém. Em suas margens devem ainda existir tribos de cultura marginal. Como um dos afluentes mais importantes do Turúnu, e sempre citado o Wehánama, sede dos Tunayána.

Do lado esquerdo, juntamente com seu formador, o Panamá, o maior afluente do alto Trombetas é o Kachpakúru. Nas regiões das cabeceiras, bem próximo aos campos gerais, êle possui um braço direito, o Kurátari digno de menção pelos índios que ali residem. O Kah.yáhó, o Onomto-húmu e outros, só temporàriamente são habitados. Finalmente, deve-se acrescentar o já mencionado Erepecuru, situado no baixo Trombetas, cêrca de $50 \mathrm{~km}$ acima de sua foz.

O Nhamundá é relativamente pobre de afluentes e êstes são também de pouca importância para o nosso objetivo. Citemos apenas o Ipitinga, sede dos Katuêma ou Totóimo. Aproximadamente na altura do equador, o Nhamundá divide-se, a leste, no Nhamundá pròpriamente dito, ou Chamená; a oeste, no Wíni. O Nhamundá é um rio das regiões intermediárias; não tem as suas fontes no divisor real do Acaraí e sim em alguns dos seus contrafortes. Entre as suas cabeceiras e as serras fronteiriças estendem-se campos que, embora interrompidos por restingas de mata, se prolongam até a Guiana Inglêsa e a região do Rio Branco.

A parte leste do Pará setentrional é ocupada pelos sistemas fluviais do Paru, ou seja o Paru do Leste e o Jari. Ambos têm suas origens na serra Tumucumaque. O alto Paru divide-se no Okômôkê ou Paru pròpriamente dito, e a leste, no Matawarí. Êste último é hoje o "habit bastante conhecidos de nome. O maior afluente do Paru - o Chitaré - vem do oeste, da zona intermediária dos grandes campos gerais do Erepecuru, que é a região ainda inexplorada dos Pianoí, igualmente selvagens. Paru e Jari são o "habitat" principalmente dos Urijuyána e Aparái. Êstes últimos, por sua vez, estendem-se até o curso superior dos rios Maecuru e Curuá de Alenquer, que são dois rios menores da região intermediária entre o Erepecuru e o Paru. As suas cabeceiras estão situadas nos divisores de água secundários, porém não na serra Tumucumaque. O Maecuru, dizem os Aparai que se origina, tal como se dá com o Kuhá do Trombetas, de um enorme lago central. 
Tendo em vista que o presente trabalho trata também dos índios das zonas vizinhas do Pará setentrional, incluiremos aqui os seus rios principais .

A oeste, as notas colhidas sôbre tribos indígenas estendem-se até - Jatapu, afluente do Atúma ou Uatumã, no Estado do Amazonas, onde também se encontra a sua foz. Ao norte, em território holandês, são đignos de menção o rio Chipariwíni e seus numerosos afluentes como: Marawíni, o Kuruní, o Kutári, o Maráka, o Ápi-égu, o Akalapí, o Kuêní, c Paráime etc. Destacam-se ainda os rios Tapananí (Tapanahoni) e Parúma (Paloemeu) com o seu maior afluente o Tapái (Tapaje). E, mais adiante, o Urumarí (Oelemari) e o Arawá com o seu tributário principal, o Itani, que, freqüentemente, é chamado de Aritaní ou Aritawíni pelos índios.

Tôda essa região aqui delineada é conhecida, cartogràficamente, apenas em seu traçado geral. A respeito das terras vizinhas ao Acaraí e Tumucumaque, alguns esclarecimentos foram trazidos pelos excelentes trabalhos da Comissão de Limites holandesa e, notadamente, da brasileira. As grandes zonas intermediárias, porém, tanto entre o Rio Amazonas e a serra de Tumucumaque como entre os vários cursos dágua, ainda hoje são "terra incógnita", manchas em branco no mapa do Brasil.

\section{II - Habitat e densidade demográfica}

Outrora, a região que acabamos de delimitar era grandemente povoada por índios e ainda hoje o é, relativamente. O "habitat" indígena começa, geralmente, um pouco abaixo da linha equatorial, ou seja, na região das cachoeiras que se estendem em três séries maiores entre 1 (um) grau de latitude sul até um pouco acima do equador. Essas cachoeiras são produzidas pela arrebentação dos rios sôbre os degraus que correspondem às diferenças de nível entre o rio Amazonas e o planalto guianense. Entretanto, é de notar que sòmente poucas tribos habitam os rios pròpriamente ditos. Uma exceção é o Paru de Leste, em cujas margens se acham os centros demográficos dos Urukuyána e Aparaí. A maior parte dos índios, porém, vive nos igarapés e afluentes e aí também, de preferência, nas regiões das cabeceiras. No verão, quase sempre descem aos rios principais para pescar, apanhar quelônios e procurar seus ovos. Contudo, suas plantações e malocas se acham distantes, no interior. Esta é, sem dúvida, uma das razões por que os índios em geral, mas especialmente os da Trombetânia, mantêm pouco contacto com os civilizados do rio Amazonas, bem como da existência, ainda hoje, de muitas tribos desconhecidas naquelas regiões.

Nos respectivos mapas, as mais das vêzes designam-se os índios ali residentes por nomes gerais, tais como "Karíb", "Karipuna" ou coisa que o valha, com pouquíssimos nomes tribais entremeados. Como mos- 
tram as notas a seguir e o "corquis" de mapa anexo, foram-me indicados até agora mais de cem nomes tribais. Dessas tribos, até hoje visitei dezoito em suas próprias aldeias e tive contacto com dezenove em viagens ou em malocas de grupos por mim visitados. As restantes indicações sôbre tribos são informações obtidas exclusivamente dos índios.

Esta grande quantidade de nomes indica que, num território relativamente limitado, não se pode tratar de grandes "nações", mas apenas de pequenos grupos - tribos com vida autônoma - que, no fundo, não passam de "sipes" (de associações tribais outrora maiores, em. bora ligadas mui fracamente entre si), com a mesma língua e culturas uniformes. Entre os Tiriyó, por exemplo, isso me foi explicitamente declarado. Ali, as seis (pelo menos) subtribos ou grã-sipes formam o povo dos Tiriyó. A elas pertencem também os Tiriyó "bravios" com os quais há pouco contacto, mas que são reconhecidos como do tronco daquele povo. Não é possível ventilar, aqui, o problema de terem as atuais "sipes" ou pequenas tribos se isolado do bloco principal ou, ao contrário, se formado de elementos primitivamente alheios a êsse povo (a que hoje pertencem), aculturados ao bloco principal e a êle assimilados. Parece-me, porém, que se verificaram ambas as coisas.

O Karíb, em geral, não tem tendência para grandes aglomerações étnicas. Prefere o sistema das pequenas "sipes" em forma de habitações dispersas. Os maiores grupos étnicos que encontrei não passavam de 250 a 300 almas, as quais se repartiam ainda entre 4, 5 ou mais malocas, como, por exemplo os Marah.tchó, do Panamá, que ali possuem seis malocas. Note-se, porém, que êles pertencem aos Tiriyó, que, por sua vez, (com exclusão dos Tiriyó bravios) possuem mais de trinta malocas e contam aproximadamente 1.000 a 1.200 almas.

No decorrer dos anos, tentei organizar uma estatística; contudo, dadas as circunstâncias, ela não é inteiramente fidedigna. Teòricamente, ela dá como cota-média cêrca de 30 pessoas por maloca, enquanto as cifras reais variam de 15 a 50 , sendo raro encontrar-se uma maloca com mais de 50 habitantes. Neste caso, quase sempre se trata de hóspedes que, durante semanas e meses, aumentam o número habitual dos moradores, mas que, na realidade, não pertencem ao "estoque" da aldeia.

Como se pode verificar pelo mapa incluso, nesta região foram registrados, até agora, cinco grupos dialetais Karíb mais importantes. Não foi incluído um número não pequeno de tribos dada a falta de elementos para uma classificação exata. Se ouso fazer uma avaliação do número aproximado de índios ainda ali existentes (pois, as mais das vêzes, tais avaliações são inexatas e exageradas), baseio-me nas já mencionadas estatísticas parciais. Teriam, então, as tribos classificadas:

1) da zona oeste da Trombetânia aprox. 1.500 almas,

2) da zona central do Trombetas aprox. 300 almas, 
3) da zona leste do Trombetas aprox. 1.200 almas,

4) da zona do alto Paru-Jari (grupo Urukuyána) aprox. 300 a 400 almas,

5) da zona do médio Paru-Jari, inclusive Maecuru e Curuá de Alenquer (grupo Aparaí), aprox. 250 a 300 almas, o que daria um total de 3.500 indios.

A esta soma devem-se acrescentar as tribos bravias, bem como outros grupos ainda à espera de classificação e que, numèricamente, perfazem quase a metade das tribos conhecidas, com um número de almas provàvelmente igual ao delas, de maneira que o total se elevaria a 6.000 7.000 indios.

Chega-se a resultado quase idêntico por outra via. Calculando-se, por região, o número de indivíduos dos vários grupos (p. ex. dos Wabú do Nhamundá, dos Tiriyó nas cabeceiras do Paru de Oeste, dos Warikyana nas zonas encachoeiradas do Trombetas-Cachorro), a avaliação dá em média mais ou menos 60 pessoas por tribo. Aplicando êste resultado, colhido de zonas parciais, como cota média das tribos, torna-se a obter, com as quase 100 tribos conhecidas, um número de 6.000 índios ou mais. Quero crer que êsses cálculos se aproximam bastante da realidade.

Este seria, por assim dizer, o resultado teórico; todavia, devo advertir que, "in concreto", o explorador terá pouca oportunidade de constatar os números indicados e, por isso, poderá sentir-se desiludido em suas pesquisas de campo. E' que, devido à tendência dos Karíb para um certo isolacionismo em moradias dispersas, o pesquisador encontrará apenas pequenos grupos. Um estudo geral sôbre cada um dêsses grupos culturais ou cada uma dessas famílias será como um mosaico: hé de se compor, conforme as circunstâncias, de estudos parciais numerosos e quase idênticos.

\section{III - Divisão lingüústico-cultural}

Como já foi dito, a região que acabamos de considerar é habitada, quase exclusivamente, por uma população Karíb. Outros grupos lingüísticos ali aparecem em número excessivamente pequeno. Por exemplo, uma invasão Aruák nas cabeceiras do Mapuera, parcela da tribo dos Wapichiyána, ou ainda um grupo muito isolado do ramo Tupí, num afluente esquerdo do Maecuru - os quase extintos Apama. (Possivelmente exista ainda um segundo grupo Tupí na altura do Kurátari, na área intermediária entre o Trombetas e o Erepecuru. Mas isso não está suficientemente comprovado. [ver: Tchikoyána]). Outros grupos Tupí encontram-se nas áreas marginais: os Wayámpi ou Oyampí do Jari-Oiapoque até as cabeceiras dos afluentes da margem direita do Itani e, mais para o norte, os Mêrêyó, (que é a designação Karíb dos Emerillon, na 
Guiana Francesa). Nas ainda desconhecidas regiões intermediárias do Jatapu-Nhamundá-Turúnu etc. provàvelmente ainda vive certo número de grupos marginais, de cuja classificação lingüística nada consegui saber. As informações indígenas limitam-se, na maioria dos casos, a citar romes de tribos e alguns elementos culturais.

Um olhar sôbre o mapa revela, ao mesmo tempo, a divisão interna dos grupos Karíb. Baseado no material coletado em 15 viagens, creio que a classificação dialetal e a distribuição geográfica dos vários grupos, tal como o mapa o indica, podem ser consideradas certas. Na bacia do Trombetas pròpriamente dita encontram-se, portanto, três grandes grupos Karíb, aos quais se juntam dois menores no Paru de Leste-Jari. São êles:

1) os Parukotó-Charúma, nas regiões ocidentais, do Jatapu através do Nhamundá, Mapuera, Turúnu até o Trombetas;

2) os Waríkyana ou Arikiéna, no setor central, nas zonas próximas, nas margens do próprio 'Trombetas;

3) os Pianokotó-Tiriyó, na parte ocidental da bacia do Trombetas, do Panamá através do Marapi e Paru de Oeste até o Okôm môkê e Matáwari (alto Paru de Leste), como também nas cabeceiras do Chipariwíni, Tapanani e Paruma;

4) os Urukuyána no Paru de Leste, Jari, Itani e Paruma;

5) os Aparaí no mesmo Paru de Leste, Jari, mas também no Maecuru e Curuá de Alenquer.

Êsses grupos, do ponto de vista geográfico, são pràticamente separados por limites naturais. Assim, o Trombetas é um autêntico divisor entre os Charúma e os Pianokotó. O pequeno grupo Charúma, no $\mathrm{Pa}$ namá-Iriyó, é de origem mais recente e proveio de interêsses mercantis das tribos ali residentes. Considerando-se os Waríkyana situados entre êles, têm-se a impressão de que êste grupo étnico aí se tenha intrometido como uma cunha. E de fato assim é, segundo as tradições migratórias dos Waríkyana: seus antepassados, vindos do rio Amazonas, emigraram para a bacia do Trombetas.

Outro separador de grupos acha-se na região dos campos gerais que se estendem do Marapi, através do Paru de Oeste (Erepecuru) até o Chitaré e o Okômôkê. As serras do Chitaré formam uma linha divisória entre os Tiriyó e os Urukuyána-Aparaí.

Apesar de êsses 5 grupos formarem, de per si, unidades autônomas e distintas, revelam um denominador cultural comum que poderíamos chamar de "karaibismo" ou, talvez melhor, "karibismo", encontrado em todos os grupos, uma espécie de cultura "standard", com variantes ambora. Se a atual "cultura Karíb", especialmente em seus elementos materiais, se deriva dos Karíb primitivos, é outra questão, e aqui não po- 
demos discuti-la. Note-se, porém, que a maioria das informações indígenas nega êste fato. Nem por isso se deixa de constatar certa uniformidade em todos os setores da vida Karíb: na linguagem, na cultura material, na estrutura social e, também, no conteúdo das idéias religiosas, pelo menos no que diz respeito ao xamanismo atual.

Na linguagem: Encontra-se nela um número fixo de radicais e palavras, uma espécie de "Basic-Cariban", que existe em todos os dialetos e com o qual (como bem o sei pela experiência de muitos anos) inicialmente o forasteiro pode se defender, até que tenha aprendido o novo dialeto do grupo em que se acha.

Na cultura material: Na maior parte dos processos ergológicos, reinam técnicas ou sistemas de trabalho uniformes, tanto no que se refere a trabalhos de madeira (arcos, bancos, canoas, ralos etc.), como à tecelagem (rêdes, tipóias), à olaria (técnicas em espiral), à tecelagem de arumã e palha (peneiras, paneiros etc.), e ao uso das matérias primas em geral. As divergências se manifestam antes na forma que na técnica de trabalho como tal, e determinam, desta maneira, as peculiaridades $e$ características dos vários grupos étnicos.

Na estrutura social: Os grupos adotam o sistema patrilinear. A criança pertence à família, sipe ou tribo do pai, e os membros da sipe paterna moram geralmente juntos. Uma exceção é apresentada pelo grupo central dos Waríkyana, que são matrilineares. A criança pertence à família da mãe. Outrora, também na questão de moradia obedeciam ao sistema matrilocal. Pela desagregação dêste grupo, porém, a matrilinearidade já está bastante abalada, se é que não está quase extinta. Tôdas as outras instituições jurídicas, porém, principalmente o direito de propriedade, os ciclos de trabalho etc., são essencialmente as miesmas entre todos os grupos.

No setor religioso: A base da religião é constituída por um sistema monctésta (entre os Waríkyana, p. ex., o Ser Supremo é imaginado sob a forma do sol ou da luz primitiva). Sôbre êste monoteísmo, porém, sobrepõe-se outro sistema religioso, de cunho panteísta, e que, em última análise, dá como resultado um pandinamismo. O conceito do índio é o seguinte:

Tudo o que existe, possui fôrças que se irradiam e agem sôbre os cutros sêres. Assim, cada ser existente - não só os sêres "vivos", como também as pedras, as serras, os caminhos etc. - é, simultâneamente, emissor e receptor de fôrças. Estas são, quanto aos efeitos, boas ou más. conforme sejam úteis ou nocivas ao respectivo ser (p. ex. ao homem). Predominando a influência maléfica, originam-se males, doenças etc. Também o feitiço se alicerça sôbre essa idéia básica e consiste no enfra- 
quecimento intencional das fôrças benéficas de determinado indivíduo, de maneira que as fôrças más dominam, produzindo doenças, morte, paixão, "panema" etc. Cabe ao pajé desfazer o feitiço e restabelecer o equilíbrio de fôrças no indivíduo. Visto cada fôrça ser um "agens", ela é imaginada como "persona". As fôrças tornam-se, destarte, espíritos. E' tarefa do pajé acalmar essas "fôrças personificadas" ou espíritos, cuja atividade se exerce através de materiais (plantas, animais, pedras etc.). Por isso, o pajé também sobe ao mundo dos espíritos e ao céu. O pajé Karíb tem, pois, muita coisa em comum com o xâmã da Ásia. Parece-me importante a observação de que em nenhuma tribo Karíb o pajé exerce a função de sacerdote. Êle não é mediador entre - Ser Supremo (portanto, Deus) e a parte espiritual do homem (a alma). E', exclusivamente, o intermediário entre as fôrças personificadas, os espíritos, e o homem considerado como um centro de fôrças.

Em suas tradições: Tôdas as narrativas que conheço sôbre as migrações dessas tribos indicam o oeste, e em parte o noroeste, como rumo de emigração. Elas se referem a montanhas gigantescas com vulcões ("serras que cospem fogo"), a fontes e a lagos de água quente. Também se conservou em todos os grupos a tradição de que os seus antepassados eram antropófagos, de que ambos os sexos andavam completamente nus, de que o seu tipo de arma primitivo não eram arco e flecha e sim a borduna, em forma de cacête, e de que - o que é mais importante - a sua atual cultura foi-lhes trazida por outro povo, a cultura de seus antepassados tendo sido, por conseguinte, bastante primitiva.

Escapa ao objetivo dêste estudo discriminar detalhadamente todos êsses elementos comuns, bem como as disparidades que existem entre os vários grupos. Todavia, indicaremos pelo menos alguns pontos a êste respeito.

\section{a) Diferenças lingüísticas}

$\left.1^{\circ}\right)$ No setor das mudanças fonéticas, aparece principalmente a modificação de consoante "H". Transforma-se, freqüentemente, o "h" em "p" ou " $p$ " (= "p" ou "f" bilabiais) ou até em "Stocklaut" (em inglês "glottal stop"). Se não me engano, foi Koch-Grünberg quem definiu o "Stocklaut" como uma esquisita interrupção no meio da palavra ou da frase. Exs.: os Waríkyana denominam o céu = Kahú; os PianokotóTiriyó, Urukuyána e Aparaí = Kapú; os Parukotó-Charúma = Kapú. O "Stocklaut" aparece principalmente em composições, p. ex., $\mathrm{Ka} /$ yana (de Kahu-yana) em vez de Kah.yana; Warí/kyana (de ariha-ku-yana) em vez de Waríkyana, etc. Algumas vêzes, porém, mesmo nas divergências interdialetais predomina o " $\mathrm{h}$ " aspirado, p. ex., entre as tribos do Nhamundá (grupo Parukotó): céu = Kahí. 
2) Nos sufixos nominais: a quantidade, aplicação ou respectiva eliminação dêsses sufixos diferem entre os vários grupos. Os Waríkyana possuem bem uma dúzia de tais sufixos nominais. Entre os ParukotóCharúma seu número já é mais reduzido. Entre os Pianokotó-Tiriyó, são menos ainda, e a maioria dos sufixos nominais, entre êles, condensou-se no sufixo geral: - i. Da mesma forma, a aplicação ou eliminação dessas partículas é muito mais ampla e complexa entre os Waríkyana do que entre os Tiriyó ou mesmo os Charúma.

3) Nos sufixos em geral, especialmente nos sufixos verbais: enquanto no dialeto Waríkyana aparece, muitas vêzes, um acúmulo de prefixos, infixos e sufixos que dificultam a construção do verbo ou da frase, os dialetos Charúma e Tiriyó são mais simples e mais claros.

4) Nas preposições (de nossa língua), que são expressas por posposições. Embora estas sejam essencialmente as mesmas em todos os dialetos, entre os Waríkyana, p. ex., são muito mais especificadas.

5) Nas negações: em tôdas as tribos Karíb desta região encontram-se as mesmas negações: -wa, awa, nya, - hera, —ra, —ta, —taki... Sua aplicação, porém, muitas vêzes difere. Assim, entre os Waríkyana, -hera é negação verbal, enquanto a negação do adjetivo termina em - taki. Os Aparaí e Wáyana possuem a negação adjetiva em -hera (-pera), enquanto os 'Tiriyó também usam a negação verbal em - ta e -wa.

Essa rápida enumeração de algumas diferenças dialetais já é suficiente, embora muito se pudesse acrescentar. Uma exposição minuciosa dos várics matizes dialetais Karíb escapa, porém, ao objetivo do presente trabalho.

\section{b) Diferenças religiosas e sociais}

Uma das principais já foi mencionada: contràriamente a todos os outros grandes grupos da região, que adotam o sistema patrilinear, o grupo central dos Warikyana, do Trombetas, tem organização matrilinear, a qual, porém, está se desarticulando paulatinamente. Assim, entre êles a residência não é na comunidade da sipe paterna, mas da sipe materna. Também na transmissão hereditária de cargos obsierva-se o princípio matrilinear. Mesmo a mulher pode ser "Tuxaua" ("dona" da aldeia), embora, em públicn, seja substituída, na maioria dos casos, pelo irmão ou filho mais velho (raramente pelo marido). Nos assuntos referentes a casamentos ou divórcios, quem decide é a "mãe" da sipe ou da família. Contudo, o filho mais velho (ou, na falta dêste, o seguinte) é quem executa em público essas determinações. Nas tribos patrilineares, a palavra decisiva cabe ao homem. Diga-se de passagem. porém, que mesmo neste caso êle exerce as prerrogativas que o direito 
tribal the confere sob a influência da mulher, fazendo-lhe a vontade na maior parte das vêzes. A diferença, portanto, é apenas de natureza jurídica, desaparecendo quase sempre na prática.

$\mathrm{Na}$ forma matrimonial também se observam diferenças. Entre os Parukotó-Charúma, Warímyana e Urukuyána, a poligamia é lícita e reconhecida. Encontrei homens com três mulheres e um até com quatro. Em geral, porém, trata-se apenas de bigamia. Já os Tiriyó são monógamos; sòmente aos chefes de sipes é permitido possuir uma segunda mulher. Entre os Marah.tchó do Panamá (que são também Tiriyó) a bigamia foi parcialmente adotada talvez pelo estreito contacto com os Charúma. Outrossim, os Aparaí são fundamentalmente monógamos e uma bigamia ocasional só é tolerada e explicável por influência Wáyana. Os dois únicos Aparaí bígamos que conheci possuíam uma espôsa Aparaí e outra Wáyana e moravam na zona limítrofe dessa tribo, um pouco abaixo do Chitaré. Provàvelmente a situação política entre as duas tribos tenha concorrido para êsses casos de bigamia.

Mais profundas são as diferenças nas práticas que se baseiam em idéias e costumes religiosos, como p. ex., o modo de se desfazerem do defunto. Os Waríkyana, os Pianokotó-Tiriyó e os Aparaí praticam exclusivamente o sepultamento no chão, com o cadáver de cócoras, embora o modo de colocar o defunto (sentado, deitado de costas), bem como o formato da cova (redonda, retangular) seja diferente entre as várias tribos. Os Urukuyána adotam, além disso, a cremação dos cadáveres. Entre os grupos Parukotó (do oeste), porém, existe apenas a cremação, quase sempre ligada ao endocanibalismo, caso em que se ingere a cinza dos ossos do defunto misturada com bebidas.

No setor do xamanismo constatam-se também algumas diferenças. Entre os Parukotó-Charúma nunca ouvi dizer que as mulheres pudessem ser pajés. Os Waríkyana narram que, outrora, existiram ocasionalmente entre êles pajés femininos. Os Aparaí e Urukuyána, todavia, ainda hoje possuem pajés femininos. Ou, para ser mais exato: os Aparaí atualmente não têm nenhuma mulher atuando como pajé, porque a última foi assassinada por um balateiro civilizado, mais ou menos em 1955. Mas entre os Wáyana ainda conheci duas.

\section{c) Diferenças na cultura material}

Como já foi mencionado, essas diferenças consistem menos na técnica de elaboração do que na forma.

Arcos e fiechas: Tôdas as tribos do Trombetas exibem como base dos seus arcos, em corte transversal, um triângulo que no seu ângulo interior (no "peito") é ligeiramente arredondado, enquanto do lado exterior é achatado ou meio côncavo. Nas tribos do Paru (Aparaí, Wáyana), ao contrário, os arcos são de corte transversal quase redon- 
do. A emplumação típica das flechas, entre essas tribos, também varia de grupo a grupo e seus feitios permitem identificar a origem das flechas. As que são utilizadas na pescaria, porém, nunca têm emplumação.

Clavas e bordunas: Tôdas as tribos possuem clavas chatas. As suas linhas laterais, que variam entre curvas e retas, revelam o feitio típico das várias tribos. Bordunas de base redonda, ou "casse-têtes", são possuídas apenas pelos três grupos do Trombetas; entre os Wáyana e Aparaí não são usadas. As poucas que ali encontrei, eram de fabricação Tiriyó.

Tecelagem e trançados: $\mathrm{Na}$ tecelagem observam-se outras divergências. Os Pianokotó-Tiriyó usam uma espécie de bôlsa (pequena c'esta), fabricada com uma só fôlha de palmeira e que apresenta, ao longo da parte externa superior, uma amarração em forma de trança. Esste tipo de cesta é desconhecido nos demais grupos. Pequenas cestas com tampa (tipo caixa) faltam completamente entre os Wáyana e Aparaí, a menos que as tenham adquirido dos Tiriyó da região das cabeceiras. Usam-se apenas "caixas" grandes de arumã, que chegam a ter 1 (um) metro de comprimento, para guardar os enfeites de penas de arara. Os Parukotó-Charúma, entretanto, fabricam cestinhas de arumã (tipo caixa) muito estreitas e interessantes, com desenhos em prêto e branco ou vermelho e branco, e bonitos enfeites de pena. Êste tipo de cestinha, por sua vez, falta a todos os outros grupos.

A construção das moradias, especialmente das casas redondas, também difere. Os Pianokotó-Tiriyó e, em parte, os Parukotó do Mapuera, possuem "casas de pião" fechadas. Entre os demais grupos, elas são abertas, sem paredes. Entre os Tiriyó, a cobertura de palha se confunde com as paredes, originando-se assim uma casa redonda quase tipo "colmeia". Nos outros tipos, cobertura e armação da casa, com ou sem paredes, formam dues partes distintas. A cobertura cônica, terminando em ponta saliente, é colocada sôbre o aro que une os esteios. Entre os Parukotó-Charúma a cobertura da casa desce em linha reta, ao passo que entre os Urukuyána-Aparaí, ela desce arredondada e tem o beiral saliente, dando ao conjunto da cobertura a forma de sino.

A lista dessas divergências interkaribes pode, naturalmente, ser bastante ampliada, para abranger canoa e remos, rêdes e tipóias, tangas e enfeites, casas de oitão, tapiris etc. Todavia, quis apenas ressaltar que, apesar da referida "cultura standard", essas discrepâncias de fato existem. E elas são significativas porque permitem deduções quanto ao passado indígena, à multiplicidade da composição étnica do atual ramo Karíb e, também, quanto ao grau de estagnação cultural. Em parte, tais conclusões se podem tirar da aculturação de tribos outrora marginais, que se assimilaram a grupos de cultura um pouco superior, tendo se imobilizado 
em seu desenvolvimento por falta de novos estímulos indígenas. Assim, em tôda a cultura Karíb, em todos os setores da vida indígena, verifica-se uma decadência crescente. O contacto cada vez mais estreito com elementos da civilização moderna destrói a antiga cultura autóctone, fadada a se extinguir.

Existem, portanto, diferenças específicas entre os grupos, formandose, por assim dizer, pequenas províncias culturais dentro da cultura geral. Fato similar observa-se entre povos e países altamente civilizados. Certas regiões conservam suas peculiaridades cultur îs sem que isto diminua ou perturbe a uniformidade cultural do país ou do povo. Após anos de observação, tem-se a impressão de que, em comparação com núcleo básico, as diferenças encontradas são superficiais e a cultura dessas tribos Karíb é essencialmente uniforme.

\section{IV - Nomes tribais e designações de grupos}

Nem todos os nomes mencionados pelos índios como designações tribais são, de fato, autodenominaçiões dessas tribos. Aliás, é discutivel se c índio possui realmente denominações étnicas no sentido que damos ao têrmo. Freqüientementé investigações mais exatas demonstram que o sentido das suas autodenominações é, mais ou menos, "nós..." ou "homens, gente..." ou coisa semelhante, afirmação esta que, certamente, ninguém põe em dúvida. As restantes autodenominações referem-se quase sempre ao seu "habitat", à paisagem, ao rio onde moram ou, ainda, a peculiaridades de seu povo, caso em que os nomes muitas vêzes lhes foram dados pelos vizinhos e, por não serem pejorativos, adotados. Como exemplo do primeiro caso, podem servir os nomes das tribos "Totó"; Totoró, Totóimo, Totókumu, Kalína e outros, cujo radical: "Totó" significa, homem, gente ou, mesmo, inimigo. Para o caso de denominações referentes ao "habitat" cito os nomes: Waríkyana, Kachúyana, Kahúyana e Kah.yana, que não significam senão gente, povo ou moradores (-yana) do Amazonas (Ariku-ru), do rio Cachorro (Kachúru) ou do rio Trombetes (Kahú; kah.). Para o último caso, o nome dos Prôuyana ou Índios Flecha é característico: êsses índios têm o costume de levar uma flecha sempre que, por qualquer motivo, saem da maloca. Donde o seu nome. Ouvi esta explicação tanto dos próprios Prôuyana, como dos Arámayána, Wáyana, Aparaí, Marah.tchó e Kachúyana. Dá-se o mesmo com os Aparaí. Êsse nome deve ter sido adotado do Tupí, num tempo em que os Aparaí ainda mantinham estreito contacto com tribos de língua tupí. "Aparaî" provàvelmente significa "Erco pequeno". De fato, os Aparaí ainda hoje usam arcos muito pequenos, que seriam considerados, por outras tribos, como "arcos de criança".

Grande parte dos nomes tribais que se ouvem são simplesmente apelidos que, por vêzes, encerram certo desprêzo. Não raro são aplica- 
dos a tribos de outros dialetos, mas não exclusivamente, pois ocorrem também dentro do mesmo grupo étnico e dialético. Alguns exemplos:

Amplamente conhecidos são os Mawayána ou "Índios Sapo". São descritos como tipcs altos e fortes. Disseram-me: "Mais altos que tu!" (Tenho $1,72 \mathrm{~m}$ ). Em relação à forte compleição do tronco, as pernas são finas e longas demais. Dizem os índios, maldosamente, que êles se parecem com um sapo morto e esticado, de pernas finas e compridas, e de barriga volumosa. Aos Faruarú do Mapuera - seus parentes mais próximos - chamam-nos também "Máwayána", mas, ao mesmo tempo, afirmam: "Pròpriamente, êles são Parukotó!"

Os Aramayána são chamados também de Aramagotó (que significa: "Indios Abelha Preta"), apelido que lhes provém da sua tez um pouco mais escura. Inquiridos acêrca de seu nome, respondem prontamente: "Tiriyó". Não aceitam de bom grado a denominação de "Araməyána", embora dêem pouca importância ao fato. O mesmo acontece com os Arimiyána ou Apimihotó, os "Indios Cuatá"; os Pianokotó ou "Índios Gavião Real"; os Okômoyana ou "Indios Caba"; os Rêrêyána ou "Indios Vampiro" etc.

Certo número de tribos têm nome de animais: os Ewarho-yána ou "Índios Anta", porque moram no "igarapé da anta" (ewarho-tuna); os Arimiyána, Arámayána, Okômcyana etc., dos quais já se falou.

Quanto a essas tribos com nomes de animais, quero ressaltar que seria errôneo enxergar, nesses nomes tribais, grupos ou sistemas totêmicos. As atuais tribos Karíb, da região que conheço, não possuem, em vigência, idéias e tradições totêmicas. Provàvelmente algumas de suas idéias sócio-religiosas podem ser consideradas como retenções de um totemismo outrora existente. Não será fácil decidir se estas poucas idéias, aparentemente totêmicas, provêem dos primitivos Karíb ou se foram trazidas por tribos assimiladas (por ocasião de grandes migrações, guerras etc.), pois a mitologia Karíb - tanto quanto a conheço - não consiitui um complexo uniforme. Constata-se certa uniformidade apenas na crença no feitiço, na magia e no xamanismo de características sul-americanas.

As diferenças na aplicação dos nomes, bem como a multiplicidade das designações tribais, revelam que o índio, em face de povos conhecidos, destaca, em primeiro lugar, grupos individuais: as sipes ou pequenas tribos. Todavia, também classifica as tribos em grupos maiores e, neste $\mathrm{Caso}$ o critério que adota é - para consôlo dos americanistas - o mesmo da etnologia moderna: a língua. O índio distingue claramente: "gente da mesma língua e do mesmo sangue" e "gente diferente". As. sim, êle circunscreve, empìricamente, a atual posição e extensão do próprio grupo tribal e lingǘstico, embora tenha consciência de que nem sempre correu em suas veias o mesmo sangue, de que nem sempre sua 
linguagem foi como hoje (pois o dialeto dos antepessados é conhecido apenas vagamente) e de que houve muita miscigenação. Os Kachúyana consideram-se a si próprios como um povo híbrido resultante do cruzamento dos antigos Waríkyana ou Arikiêna com os índios outrora residentes no rio Cachorro e que, provàvelmente, pertenciam ao grupo Charúma (Tunayána?). E dos Káh.yana do Kachpakúru, que hoje em dia pertencem ao mesmo grupo lingüístico dos Waríkyana, declararam os mesmos Kachúyana que os seus antepassados foram Parukotó. Desta forma, a identidade de língua e sangue tem significado apenas para o momento presente.

Coisa semelhante verifica-se entre os Tiriyó, que sabem, exatamente, quais os grupos que pertencem ao seu círculo étnico e lingüístico e que, por isso mesmo, sem hesitacão, incluem nele as tribos bravias, quase desconhecidas, de cultura semi-lítica, como os Wayarikuré, Wána, Akuriyó etc., enquanto rejeitam o pequenino e igualmente primitivo povo dos Taripiyó, os quais, não obstante, estão encravados entre êles: "Não são Tiriyó! Não são dos nossos!"

$\mathrm{O}$ índio também distingue, do ponto de vista da língua, as unidades étnicas que the são alheirs. As denominações conferidas aos grupos não raro tiveram sua origem num conhecimento mais estreito de uma só tribo, seja por ter sido a primeira a ser conhecida, travando-se com ela contacto mais constante, seja porque constituía a parte mais importante daquele grupo. A primitiva designação individual da tribo estendeu-se depois a todo o grupo. Exemplo típico disto são os Charúma, que constituem, atualmente, uma pequena tribo da região do Turúnu. O seu "habitat" estendia-se outrora até a zona do Trombetas e Kafuíne. As tribos Tiriyó entraram em contacto estreito primeiramente com êles e, por seu intermédio, com outras tribos do mesmo dialeto. Por isso, também os Tunayána, os Pãkufádjana, os Awí etc. são tembém considerados "Charúma" pelos Tiriyó. Fato idêntico passou-se com os Kachúyana, que em geral chamam as tribos Charúma de "Tunayána", embora êsses ú1timos sejam apenas um grupo individual que tem sua sede num afluente da margem esquerda do Turúnu, no igarapé Wehánama (Igarapé da Flauta). O conceito de "Tunayána", dos Kachúyana, estende-se a tôdas es tribos que falam o Parukotó-Charúma. Uma prova concreta disto, tive-a numa viagem ao Mapuera (1949), da qual participaram três índios Kachúyana. Quando ouviram falar os primeiros Parukotó do Mapuera, imediatemente me explicaram: "Assim fala Tunayána! Esta gente é Tunayána!"

O grupo dialetal dos Charúma-Punayána eschende-se através do Mapuera até o Nhamundá e Jatapu; todavia, o nome coletivo aí empregado não é Charúma e sim Parukotó. Os Parukotó reconhecem os Charúma e Tunayána como tribos individuais, mas não como conceito coletivo. Êste, entre êles, sôa: Okóimo-yána (Índios Cobra Grande). 
Outro nome coletivo daquela região é Katuêma. Refere-se a tôdas as tribos que vivem entre os rios Nhamundá e Mapuera. O têrmo provàvelmente se deriva do Tupí ou da língua geral e significa "os não-bons, os maus, os selvagens". Ếsses Katuêma são subdivididos em dois grupos: "Katuêma mansos", também chamados Totókumu, e os "Katuêma bravios", as mais das vêzes denominados Totóimo. Os Totókumu abrangem principalmente os tribos do Acari e são tribos bravias aculturfdas aos Parukotó, enquanto os 'Totóimo ainda hoje são selvagens ou, pelo menos, semi-selvagens.

Juntamente com essas expressões, aparece ainda, como têrmo coletivo das tribos do Nhamundá, o nome Wabuí. Perguntei uma vez aos índios dali se já tinham ouvido algo sôbre os "Wabuí". Riram e responderam: "Somos nós, daqui, do Nhamundá. Os Chawiyána, Hichkaruyána, Kumiyána... todos êles são Wabuí".

Històricamente, porém, consta que Frei Francisco de São Marcos transferiu, em 1725, os Babuí (Wabuí, Uabuí, Abui) do Trombetas para o Nhamundá. Este mesmo Frei Francisco, a quem devemos o documento mais antigo sôbre o Trombetas, testemunha igualmente que os "Parukuatô" (Parukotó) habitavam até o Trombetas e enumera na região do Trucurim (provàvelmente o atual Turúnu) tribos Parukotó, que em parte ainda hoje moram lá e caem sob o conceito coletivo indígena: "Charúma"; assim, os próprios Sarúma (Charúma), os Pakepha (Pàkufáyana), Sereu (Chêrêú) etc. Num grupo lingüístico tão extenso existem, naturalmente, divergências interdialetais. Elas são perceptiveis, até certo ponto, entre os dialetos do Turúnu (Charúma) e os do MapueraNhamundá (Parukotó), mas, a meu ver, não são tão profundas a ponto de se poder afirmar que se trate de dois grupos dialetais diversos. Contudo, levando em conta essa circunstâncis, escolhi para designação de todo êsse grupo o nome composto: "Parukotó-Charúma".

Para o grupo central da bacia do Trombetas, pode servir como nome coletivo o têrmo Waríkyana (Aríkyana, Arikiéna, Arikêna). Os Kachúyana e Kahuyána declararam que todos os grupos que falam o dialeto Kachuyána tiveram como antepassados os Waríkyana ou Arikiêna, que se misturaram, por ocasião da suc imigração, com as tribos que viviam nos rios Cachorro e Trombetas. Dizem alguns que os Waríkyana foram também chamados de Ingarüne, embora êsses, hoje em dia, representem apenes um grupo particular. (O nome Ingarüne contém, sem dúvida, o têrmo Karíb: Karíne, Kalína = homem, índio, gente). A expressão Aríkyana, Arikiéna, por sua vez, não significa senão "gente, povo, tribos, moradores do Amazonas", porque de lá vieram. A explicação etimológica é a seguinte: o rio Amazonas entre êles é denominado: Ari-kurú, ou seja: Beiju-rio (rio Beiju). Arihá quer dizer beiju e, em sentido mais amplo, também mandioca; Ku, Kuru é o antigo 
radical de "rio" ou "água corrente". Na composição das duas palavras. o sufixo nominal - ha (de Ariha) desaparece e fica somente Ari-kuru. Mas, por ser o - ru (em Kuru) apenas uma partícula verbal auxiliar (ser, estar), que também em composição com outros radicais desaparece, origina-se o têrmo composto: Ari-ku-yána ou seja, Beiju-rio-povo, isto é, "gente do rio Beiju" ou "tribos do Amazonas". $\mathrm{Na}$ linguagem corrente, esta forma é contraída, por supressão da vogal, para Arík. yana ou Aríkyana, Waríkyana, Arikíena e Arikêna.

Entre as tribos Tiriyó, do norte, e os grupos Urukuyána e Aparaí, do leste, os Waríkyana são conhecidos pelo nome de Chikarídjana ou Tchikareyána. Com a denominação Tchikareyána designa-se, em primeiro lugar, o grupo das Ingarüne, mas o conceito também se estende aos demais grupos da mesma língua, aos Waríkyana em geral.

O grupo do leste da bacia do Trombetas, que se prolonga até o Paru de Leste, foi indicado no mapa como "Pianokotó-Tiriyó". As respectivas tribos que estão sob essa denominação designam-se a si mesmas por Tiriyó, nome, portanto, que expressa um conceito coletivo ètnicamente peculiar. Em todos os grupos que visitei, sempre ouvi, como nome tribal, a expressão Tiriyó e sòmente depois de uma investigação mais acurada especificaram-se como Rãgú, Prôuyana, Aramihh.tchó etc. O nome Tiriyó ('Türeyó, Türiyó) deriva, segundo a explicação dos Prôuyana, de "wátüre", isto é: dar cacetadas, matar com cacête. Os Tiriyó seriam, então, "o povo dos cacêtes" ou "os que matam com cacête", o que exprime, claramente, o traço característico dessa tribo: a sua ferocidade de outrora e a sua antiga arma de guerra - a borduna. Nenhum dêsses índios, porém, jamais se cognominou Pianokotó. No entanto, as designações Pianokotó, Pianakotó, Pianokwatô (Índios Gavião) existem. Baseado nas informações obtidas através de diferentes fontes indígenas, não creio que haja ou tenha havido um povo como esta autodenominaçâo. "Pianokotó" é um apelido e, ao que parece, de significação não muito lisongeira. Os Prôuyana usam-no com referência a outros grupos Tiriyó que lhes são inimigos - como por ex. os Marah.tchó - muito embora reconheçam que os Marah.tchó também são Tiriyó. Para justificar o emprêgo dêste nome, evidentemente ofensivo, assim se exprimiram: "Os antigos Marah.tchó, os velhos, êsses eram bons; mas já morreram todos. Os de hoje, êsses são Pianokotó!" No Panamá, entre os próprios Marah.tchó, essa designação - Pianokotó - é altamente cfensiva. Ignorando o fato naquela época, empreguei essa "alcunha"; o resultado quase me foi desastroso.

Pianokotó, segundo tôdas as informações obtidas, é a denominação geral usada pelos grupos Waríkyana e Charúma para tôdas as tribos Tiriyó habitantes do leste do Trombetas. O nome Tiriyó não é usado entre êles como têrmo coletivo. Em virtude do fato de serem os Ma- 
rah.tchó a tribo Tiriyó mais próxima dos Charúma e Waríkyana (ela se estende do Panamá através do Marapi até à região das cabeceiras do Kachpakúru), naturalmente foram êles os mais atingidos pela referida alcunha. Os Pianokotó, encontrados por Rondon (1928) no Marapi e Paru do Oeste, são Marah.tchó e vivem, hoje em dia, novamente nas cabeceiras do Marapi. Os Pianokotó, localizados pela Comissão Brasileira de Limites no Panamá, são também Marah.tchó. Tive oportunidade de conversar com êles sôbre o assunto. Também os Pianokotó do alto Kachpakúru são Marah.tchó, (embora aí sejam denominados Marajó). Conheci pessoalmente certo número dêles. Não existe, portanto, uma tribo Pianokotó pròpriamente dita, mas apenas, em sentido mais estreito, o grupo Tiriyó dos Marah.tchó e, em sentido mais amplo, o povo Tiriyó. Também os Pianoí, Pianoisí, Pianosirí - rêrmos dos Urukuyána e Aparaí, que correspondem ao têrmo Pianokotó dos Waríkyana e Charúma - são Tiriyó selvagens. As tribos Tiriyó e Piano, como têrmos coletivos êfrnicos, provàvelmente são idênticas. Mas, uma vez que os Marah.tchó entraram na etnologia com o seu apelido "Pianokotó" e são tratados como uma tribo à parte, distinta dos Tiriyó (êrro que precisa ser retificado), apliquei, como denominação dêsse grupo, o nome composto: Pianokotó-Tiriyó.

A leste dos Tiriyó, no Paru de Leste, encontramos os Urukuyána, que se tornaram bastante conhecidos sob esta designação, embora também ñão seja êste o seu verdadeiro nome, mas uma alcunha que outrora receberam de outros, segundo êles mesmos declararam. Mas a aceitaram e, por isso, figurarão com ela em nosso esquema. Sua autodenominação é Wáyna( Ayana, Oyana, Oiyana). Urukuyána tornou-se entre êles um têrmo coletivo, fato que tem certa importância, pois, segundo me declararam, os Opuruí ou Upuruí, por exemplo, um seu subgrupo, são igualmente Urukuyána, mas não são Wáyana. Essa subtribo Opuruí está sendo absorvida aos poucos pelos Wáyana. Em 1955, encontrei sòmente duas pequenas maloc'as Opuruí.

Devem ser contados entre os Urukuyána os chamados Pachkiyána, que são tidos por "Wáyana ainda bravios".

O nome Urukuyána tem, ao que parece, a mesma explicação que o dos Waríkyana ou Arikiêna. Em seu dialeto, como no dos vizinhos Aparaí e Tiriyó, ôuru, uru significa beiju. O nome vem a dar, pois, no mesmo: uru-ku-yána = beiju-rio-povo, ou seja: gente do rio Beiju. Parte de seus antepassados teriam sido, pois, também habitantes do rio Amazonas. Isso não significa, porém, que êles sejam idên'icos aos Waríkyana cu Arikiêna, imigrados na bacia do Trombetas. Há fortes indícios do contrário. Já a língua do grupo Urukuyána é bastante diversa até mesmo da de seus vizinhos, os Tiriyó, embora contenha elementos Tiriyó. Todavia, grande parte de seu vocabulário deve ter-se originado de ou- 
tro grupo dialetal. Destacam-se as curtas e duras consoantes finais (explosivas) p. ex.: ipok $=$ bom; chiparat $=$ (desenho de) caranguejo etc., uma peculiaridade que não se encontra nas línguas das tribos aqui mencionadas.

O último grupo é constituído pelos Aparaí, que formam uma unidade lingüística, difìcilmente associável aos outros grupos dialetais. Não é fácil dizer-se qual o grupo lingüístico Karíb a que os antigos Aparaí pertenciam ou, pelo menos, a que estavam mais intimamente ligados. Nesse dialeto, encontram-se muitos elementos Waríkyana, bem como Tiriyó. Que nele haja uma grande influência Tupí, é inegável. Também existem alguns elementos tipicamente Urukuyána. Não obstante essas múltiplas influências, tenho a impressão de que a base lingüística pode ser resumida numa combinação de Tiriyó e Waríkyana. Certeza, porém, só se poderá ter por um estudo mais minucioso do dialeto Aparaí. Todavia, é digno de nota que os Aparaí e os Wáyana, apesar de seus dialetos muito diferenciados, se assemelham em quase todos os aspectos ce sua cultura material. Pequenas diferenças verificam-se especialmente na cerâmica e, mais ainda, na pintura interna das panelas, que falta aos Wáyana; na forma mais quadrada do abano, enquanto os Wáyana adotam a forma retangular; nas linhas levemente sinuosas das clavas chatas, que entre os Wáyana são mais retas e angulosas etc. Não se estará longe da verdade afirmando que os Aparaí e os Wáyana constituem um grupo cultural uniforme, embora não o sejam do ponto de vista lingüístico.

Em alguns mapas encontram-se, nessas regiões, as designações "Karipuna", "Karipono", ou coisa semelhante. Até certo ponto, essas palavras também são têrmos coletivos, pois Karípono é um têrmo Wáyana e significa simplesmente "homens", "indios" ou, em sentido mais amplo, "tribos", "povo". Os viajantes com certeza indagavam quem morava alérn do Paru e a resposta recebida deve ter sido: "Karípono" = Gente! Homens! Tribos! Esta palavra também é empregada pelos Wáyana com referência a seus companheiros de tribo, não diretamente aparentados com êles. Contudo, não existe naquelas regiões nenhuma tribo de nome Karipono ou Karipuna.

\section{$\mathrm{V}$ - Classificação esquemática}

Tendo em vista que a nomenclatura das várias tribos, nas notas a seguir, foi compilada alfabèticamente, quero apresentar um esquema sôbre a sua inclusão nos diversos grupos dialetais, segundo as informações que pude obter:

A. Aruák: Wapichiyána

B. Tupí: Ápama 
Wayámpi (Oyampí)

Mêrêyó (Emerillon)

C. Karib:

I. Parukotó-Charúma:
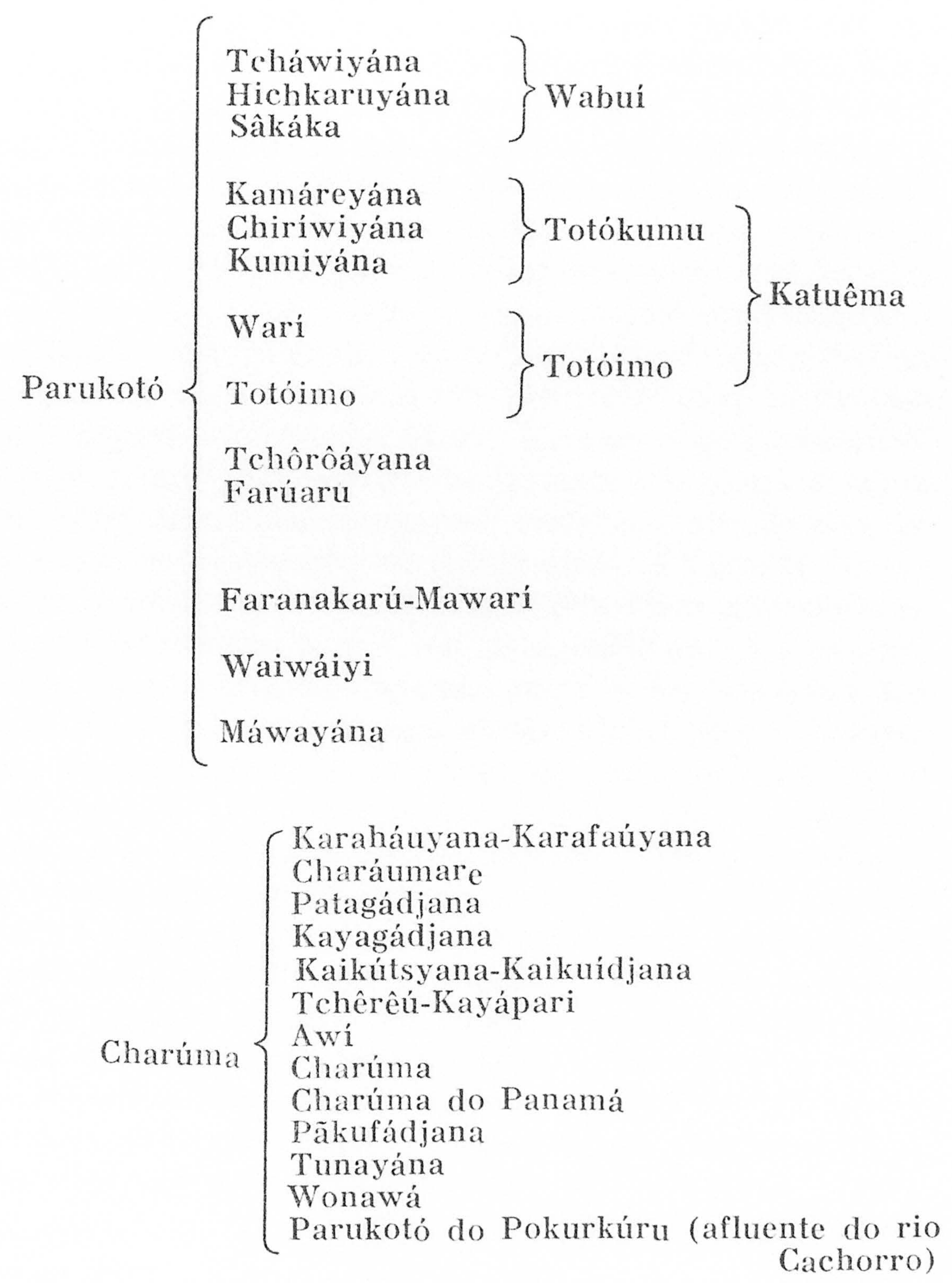

II. Warikyana:

Kachúyana $\left\{\begin{array}{l}\text { Kachúyana } \\ \text { Itchitchwáyana } \\ \text { Yaskuríyana } \\ \text { Kahúyana } \\ \text { Urumanányana }\end{array}\right.$ 


$$
\begin{aligned}
\text { Káh.yana }\left\{\begin{array}{l}
\text { Kachpakúyana } \\
\text { Káh.yana } \\
\text { Woyárama }
\end{array}\right. \\
\text { Pawiyána } \\
\text { Kuháyana } \\
\text { Ingarüne (Tchikaridjana) } \\
\text { Ewarhoyána dos campos } \\
\text { Prêhnoma do Erepecuru } \\
\text { Prêhnoma do rio Cachorrinho }
\end{aligned}
$$

III. Pianokotó-Tiriyó:

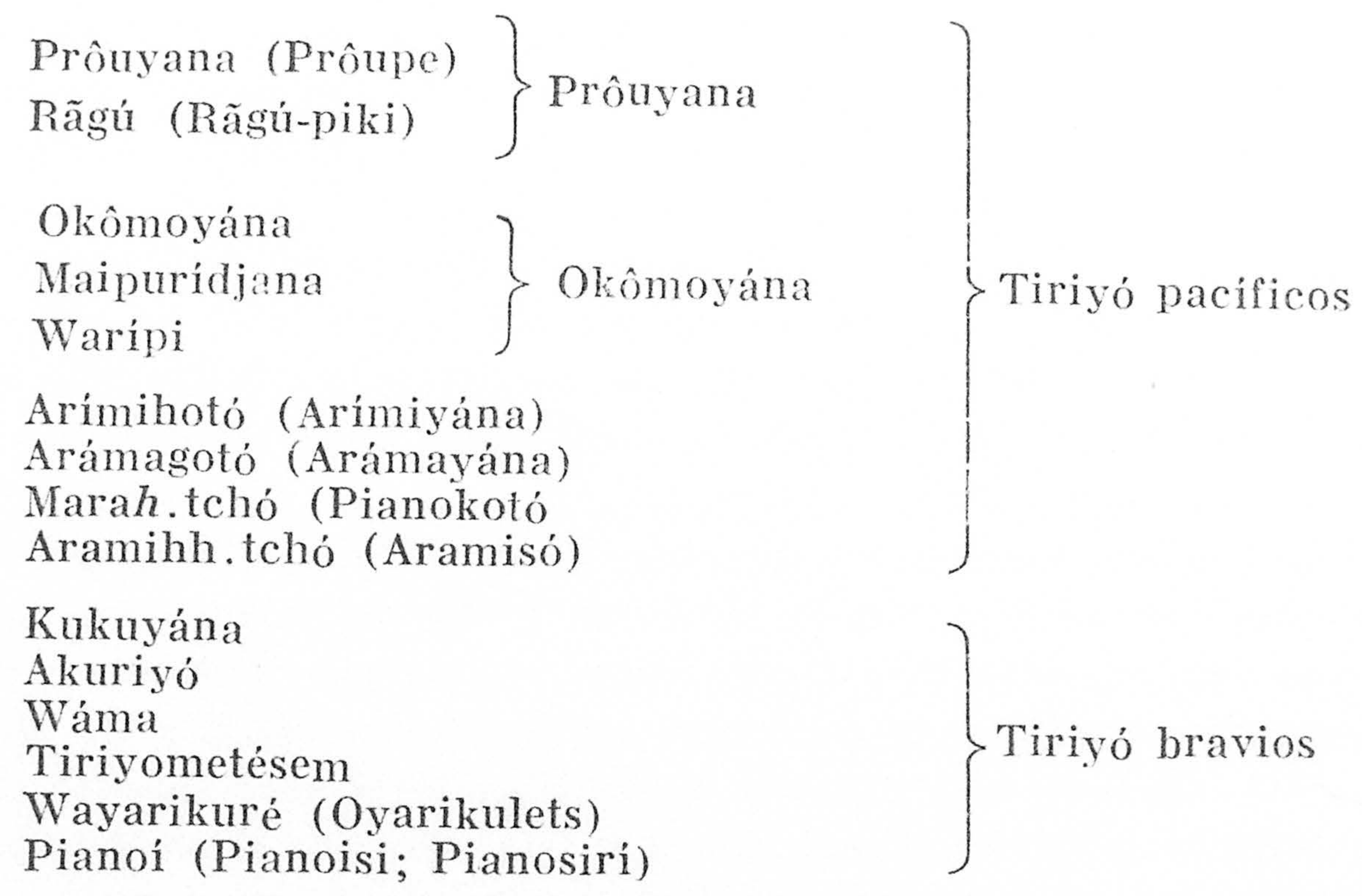

IV. Urukuyána:

Wáyana

Opuruí (Upuruí)

V. Aparaí:

Aparaí dos rios: Aparaí pacíficos

Aparaí das matas: Aparaí bravios

Tôdas as outras tribos de que há notícia por enquanto ainda não são classificáveis ou, pelo menos, ainda não o são com exatidão. Assim, provàvelmente uma parte das tribos do Kotonúru deve ser incluída no grupo dialetal dos Parukotó-Charúma. O mesmo acontece com algumas tribos não classificadas do Nhamundá. Mas, como já dissemos, faltam provas ou informações mais seguras da parte dos índios para uma classificação definitiva. 


\section{VI - Tribos bravias ou de cultura marginal}

Além do esquema precedente, outro resumo poderia interessar: o das uribos bravias de cultura marginal, semi-lítica. Entretanto, como me parecem insuficientes as respectivas notas para com elas fazer um trabaIho à parte e, por outro lado, muito extensas para figurarem como simples notas de rodapé, resolvi dedicar-lhes um capítulo especial.

Inicialmente, a pergunta: como se portam os outros índios ante as tribos bravias?

Antes do mais, convém natar quie os índios "nãu-mais-bravios" fazem uma distinção entre as tribos selvagens que pertencem a seu próprio grupo étnico e as que a êle não pertencem. Às primeiras, consideram como sendo "gente", isto é: seus semelhantes, homens, patrícios, embora menosprezando-as um pouco devido ao atraso cultural. Um exemplo frisante dêste caso é oferecido pelos Tiriyó em relação aos grupos selvagens que a êles pertencem: Wáma, Akuriyó etc. Temem-nos, mantêm pouco contacto com êles e os designam como: oide $=$ selvagens. Todavia, procuram, na medida do possível, manter boas relações com êles, pois êstes são "gente" também, irmãos de tribo, no sentido mais amplo.

Outra, no entanto, é a sua atitude para com os grupos selvagens que não pertencem a seu próprio círculo étnico. Êsses são considerados "Kaikuí", isto é, "onças" ou "bichos", e êles os matam onde os encontram (caso tenham coragem para tanto), tal como matam uma onça. Êste modo de classificar os selvagens como Kaikuí, Kaikuchí, Kaiksú ou Kamára (nomes que significam todos a mesma coisa, isto é: onça) é muito comum entre os Karíb e eu o constatei, de fato, em todos os seus grandes grupos. E como essas designações (tanto quanto conheço o assunto) hoje em dia são dadas a grupos selvagens não consangüíneos, é possível e até provável que se trate, em parte, de grupos isolados, talvez remanescentes da primitiva população das Guianas ou até de restos da população que habitava aquelas regiões antes da imigração dos Karíb. E' claro que isto não exclui a possibilidade de ter havido migrações entre as populações pré-KKaríb. Dos Taripiyó (Índios Macaco Prego) os Tiriyó declararam: Êles não são Tiriyó. Não são dos nossos! Êles são Kaikuí!" Ao que parece, falam também um dialeto diferente e, outrora, moravam mais para o nordeste, na região do Itani.

Em geral, os índios evitam o "habitat" dessas tribos bravias. Do alto do Akawãme, no Paru do Leste, os Wáyana mostraram-me uma serra que se estendia obliquamente para o Jari e me disseram: "Esta serra chama-se Kaikuí-patá (Maloca dos Kaikuí). Para lá não vai ninguém. Os Kaikuí são muito ferozes. Atacam e matam os Wáyana".

Existem ainda certas áreas desabitadas, isto é, sem indios. Também essas são quase sempre evitadas pelas tribos mais pacíficas, como p. 
ex., o alto Trombetas ou Kafuíne. Os Charúma do Panamá disseram: "Prá lá não vai ninguém: lá mora sòmente kaikuchí"! Tenho certeza, porém, de que justamente lá foram encontrados indios bravios, veredas que foram abertas quebrando-se os ramos ùnicamente com a mão e nas quais não era visível nenhum golpe de terçado. A mesma coisa se pode dizer das regiões das nascentes do Turúnu, Kotonúru, Nhamundá e Jatapu. Parte dessas tribos bravias evidentemente ainda são Karíb na idade da pedra. Outras, porém, com certeza não são Karíb, especialmente os primitivos do alto Nhamundá e Jatapu. De alguns, os Chawiyána me declararam explìcitamente: "Não se compreende o que êles falam"3.

Os "Kaikuí", portanto, são as tribos bravias. Explicam-se, assim, certas informações em parte mal interpretadas pelos exploradores, quando, por exemplo, os índios thes afirmavam que os antepassados desta ou ciaquela tribo tinham sido "onças bravas". O que queriam dizer com isto era: êles descendem de tribos bravias, são selvagens aculturados.

Muitas vêzes as afirmações vão ainda mais longe, como quando se diz que certas tribos indígenas se transformam em "onças" e, nesta condição, atacam aldeias e homens. Esta transformação tem uma base real em antigos costumes de guerra (de origem Karíb?): no revestimento com pele de onça (como camuflagem no lusco-fusco da madrugada?) ou no uso de cinturões igualmente de pele de onça: na pintura do corpo com manchas escuras; na imitação daquele animal, no uso, sôbre a fronte, de diademas confeccionados com garras de onça etc. Até que ponto o guerreiro se identifica com a onça, não sei bem. Deve existir, neste assunto, certo fundo religioso ou mitológico. Em todo caso, o guerreiro torna-se onça! Com certeza, pelo menos exteriormente, mas talvez, também, em sua atitude psicológica. Em vista de não estarem mais em voga êsses costumes entre as tribos Karíb mais pacíficas, torna-se compreensível, até certo ponto, a designação de Kaikuí para as tribos bravias. Tive oportunidade de ver essa indumentária de guerreiros-onças (naquela ocasião usada como adôrno de dança) entre os Kachúyana. Em suas lendas de guerra, descrevem-se êsses guerreirosonças, bem como a sua maneira de ir ao encontro dos inimigos munidos de "borduna mágica" e de charuto índio.

$\mathrm{E}$ agora, a pergunta inversa: como se portam as tribos selvagens em face das tribos vizinhas já mais adiantadas e aculturadas?

Também neste caso se depreende certa uniformidade das informações indígenas.

Como atitude fundamental, pode-se indicar a aversão a tôda influência alienígena. As tribos bravias evitam, propositada e conscientemente, qualquer contacto com outros índios, negros e brancos. 
Em algumas tribos existem mediadores escolhidos e experimentados (pawánare) que mantêm certo contacto com as tribos bravias circunvizinhas, mais para garantir a segurança do próprio grupo tribal do que para realizar grandes negócios, pois os selvagens, em geral, nem sequer almejam objetos de troca. A motivação para o contacto ocasional por parte dos bravios, provàvelmente é outra: o espaço vital torna-se, para êles, cada vez mais limitado, especialmente pelo fato de os índios mais pacíficos se retirarem cada vez mais para o interior, diante da avalanche de exploradores chamados "civilizados", vindos do rio Amazonas e das Guianas, em busca de produtos da mata, comprimindo as tribos bravias, lenta, mas visível e inexoràvelmente. Mais cedo ou mais tarde, os selvagens acabarão por assimilar-se. Cada vez mais, chegam notícias de que aqui ou acolá as tribos bravias, outrora absolutamente inacessíveis, tentaram estabelecer um tímido contacto. Com freqüência ouvi dizer isso entre os Aparaí, os Wáyana, os Prôuyana e os Kachúyána. Ainda em 1955, quando da minha viagem ao rio Paru de Leste, apareceram Wayarikuré à margem dêsse rio, pedindo "filhos" de bananeiras aos Wáyana. Parece que está se tornando sentida entre èles a necessidade de uma nova base de alimentação, pois, segundo as informações indígenas, êles desconhecem a agricultura. Em síntese, existe um convênio tácito entre os mediadores dos lugares de contacto e as tribos bravias, conforme os Prôuyana certa vez, me revelaram. As tribos bravias comportam-se pacificamente com o mediador e sua sipe. Em troca, êsse thes dá o que elas desejam. Nunca, porém deve levar consigo estranhos para as suas malocas, nem mesmo índios, e menos ainda, pretos e brancos. Caso contrário, termina a amizade e a conseqüência é: chacina e mortes. Esta é também a razão por que os índios quase sempre se calam a respeito das suas relações com as tribos bravias. E pormenores, como nomes de mediadores, lugares de contacto etc., sòmente me foram revelados sob a condição de eu não ir até lá.

A aversão a tôda influência estende-se também às coisas materiais e, de maneira estranha, particularmente aos objetos de ferro. Quase sempre rejeitam não só terçados e machados, mas também tecidos etc. Os testemunhos de pontos diferentes e muito distantes entre si, como por exemplo, do Jatapu e do Paru de Leste, coincidem neste particular, revelando uma atitude uniforme dos grupos bravios. Qual seu fundamento, em última análise, não é fácil dizer, mas quero ilustrar essa atitude com alguns exemplos.

Em primeiro lugar, o caso dos Kararáyana do Jatapu, ao qual meu informante assistiu. Alguns "balateiros" subiram o Jatapu e, chegando a um afluente, encontraram uma maloca onde havia pequenas plantações. Ante a sua aproximação, os índios fugiram. Impelidos pela fome, os balateiros apoderaram-se de algumas bananas maduras e batatas doces, 
L

e ali deixaram, como pagamento, um terçado. E, como achassem a situação um tanto equívoca - pois ficaram desconfiados com a fuga repentina dos índios - regressaram à sua canoa. Pouco depcis, apareceu ali um grupo de homens com bordunas. Andavam inteiramente nus, eram de tez bastante clara e usavam barba (por êsse pormenor, creio que se tratava dos Karará dos meus informantes indigenas). Muito irritados, injuriavam os balateiros, exaltando-se progressivamente, sacudiam as bordunas e acabaram por lançar o terçado a seus pés. A situação tornou-se crítica. Então, meu informante, armando-se de coragem, aproximou-se dêles e por meio de sinais e gestos explicou que tinham tirado as bananas simplesmente porque estavam com fome. Os indios compreenderam e aos poucos se acalmaram. Estabeleceu-se até um contacto mais ou menos amistoso entre êles, tendo os índios thes dado mais bananas. E, em seguida, foram-se embora. Todavia, não quiseram levar o terçado, em hipótese alguma, e nem sequer tornaram a tocá-lo. Os balateiros, porém, desistiram de esperar e se retiraram.

Outro exemplo é fornecido pelos Wayarikuré. Certa ocasião, tiveram algum contacto com os Mêkoro (negros mocambeiros das Guianas) e foram por êles pròdigamente presenteados. Mais tarde, encontraramse os objetos - espingardas, panos, miçangas, terçados e machados quebrados, rasgados e destruídos sôbre as pedras da margem do Matáwari. Teriam êles agido assim com receio de feitiço, transmissão de doenças ou coisa semelhante? Ou seria, simplesmente, a aversão tradicional a tudo quanto lhes é estranho? Os Tiriyó opinaram que fôra por mêdo.

Mesmo entre os Tiriyó, índios já há algum tempo pacíficos, e que iá sabem manejar muito bem terçados e machados - também êles, segundo a tradição, pertenciam ainda há poucas gerações ao grupo das tribos bravias - as armas ponteagudas de ferro (facas, punhais) não são apreciadas. Um dos meus companheiros de viagem possuía um punhal, como os que usam os cearenses. Os Prôyana descobriram-no, olharam-no e depois disseram: "Esconda esta faca, não a venda! Os Tiriyó não gostam de faca assim!"

Além dessas tribos bravias, de cultura mais ou menos marginal, existem alguns grupos primitivos já em via de aculturação às tribos vizinhas, tais como os Tótóimo ou "Katuema bravos", da região intermediária do Mapuera-Nhamundá, e os Pianoí, do Chitaré. Ao que consta, êles já possuem tudo que os vizinhos Karíb possuem, graças aos seus "pawánare" ou mediadores: boas plantações, rêdes, arcos e flechas, tangas, miçangas etc. Para os Tótóimo, êsses mediadores são as tribos do Acarí, os Katuêma mansos ou Totókumu; para os Pianoí são, em parte, os Aramihh.tchó do Okômôkê e, em parte, os Aramagotó dos campos do vizinho rio Errepecuru. Possivelmente, - há indícios disto - os Pianoí 
não passem de Aramagotó ainda bravios. Embora essas tribos estejam sofrendo um processo aculturativo no campo material, não perderam de todo sua atitude tradicional avêssa a um contacto mais estreito com as demais tribos, revelando-se até hostis neste sentido.

$E^{\prime}$ interessante acompanhar mais de perto esta escala de desenvolvimento primitivo. Um último elo, com quase completa aculturação ao nivel "standard" dos Karíb, encontra-se, por ex., entre os já bastante pacíficos Aramihh.tchó, pequeno povo que saiu da idade da pedra seguramente há duas gerações apenas. O tuxaua. Jaríhh.kato do Arakopina contou-me que tanto seu avô, como seu pai na mocidade ainda trabalharam com machados de pedra e que era cansativo fazer roça dessa maneira. Mas que agora, com o "wôwe" (machado de ferro), o trabalho tornara-se melhor e mais rápido.

Os Aramihh.tchó ainda hoje trabalham com certo número de artefatos líticos. Batedores (martelos) e raspadores de pedra ainda estão em uso; ralos de pedra, feitos de granito áspero, coexistem com ralos de flandres, feitos de latas de querosene. Até mesmo os torradores de beiju consistem em chapas grosseiras de granito, retiradas das rochas da margem do rio. O trabalho de cerâmica é pouco e insuficiente. As panelas que fabricam são feias e mal acabadas. Eles próprios o reconhecem, motivo por que preferem comprá-las dos Wáyana. Na tecelagem, porém, e na técnica de trançados de arumã e fôlhas de palmeira, são mestres. Os Aramihh. tchó gostam de contrair cesamento com os Wáyana. Desta forma, creio que num futuro não muito longínquo pouca coisa se encontrará dessas relíquias da idade da pedra, porque êles, em pouco tempo, ter-se-ão assimilado às tribos vizinhas.

A solução do problema dessas tribos selvagens, tanto de origem Karíb como não-Karíb, evidentemente seria d:đ máxima importância para o conhecimento não só da pré-história dos grupos atuais daquelas regiões, como da pré-história das Guianas em geral. A quem possa interessar um estudo dessas tribos não quero deixar de advertir, mais uma vez, que, segurtlo informações unânimes de todos os índios que conheço - e que não são poucos! - as referidas tribos bravias são extremamente desconfiadas, ferozes, agressivas e mesmo traiçoeiras.

Seguem-rse algumas notícias avulsas sôbre as tribos bravias. Os algarismos entre parênteses referem-se à numeração que elas têm no Registro Geral das tribos.

1. (1) Achikí (Índios do...): Essa tribo e seu nome não são bem conhecidos. Trata-se de índios com elementos culturais ainda da idade da pedra e que foram vistos no pequeno rio Achikí, afluente da margem direita do Paru de Leste, em cujas cabeceiras se diz que moram. Não se sabe se se trata duma nova tribo ou se dos Pianoí ou dos Páchkiyána. A última hipótese seria mais plausível, porque o território 
dos Páchkiyána alcança as cabeceiras do Achikí. E' tudo quanto se sabe a respeito dêsses índios.

2. (2) Akuriyó: São Tiriyó bravios da zona limítrofe BrasilSuriname. Têm pouco contacto com as tribos que thes são aparentadas e, segundo informações, possuem uma cultura da idade da pedra, com a contribuição de alguns elementos modernos. Os Akuriyó são tidos como maus e ferozes pela maior parte dos Tiriyó. Consta que tếm o costume de degolar suas vítimas e praticar, ocasionalmente, a antropofagia. O seu habitat é o alto Tapái (Tapage).

3. (3) Amánarawá: Em geral, são considerados extintos, mas segundo informações avulsas, ainda restam alguns pequeninos grupos no alto Nhamundá-Jatapu. E' um povo primitivo que tinha como única arma o cacête. Considerados extremamente ferozes e belicosos, conta a tradição que eram os inimigos figadais dos Karaháuyana com os quais ireqüentemente combatiam até a sua extinção quase completa.

4. (4) Amuimó: Tribo das cabeceiras do Nhamundá. Não se conhecem outros pormenores.

5. (5) Anféhh.ne: Tribo localizada entre o Nhamundá e o Jatapu. Dizem os Chawiyána e os Hichkaruyána, meus informantes, que culturalmente essa tribo está mais ou menos no mesmo nível que êles. Possuem casas redondas, arcos e flechas, bem como pesados cacêtes, e conhecem um pouco de agricultura. Todavia, não têm tecelagem (portanto, não plantam algodão), não fabricam tangas e andam completamente nus. Os homens são famosos pelo grande tamanho do pênis. Não usam pintura facial e são ainda antropófagos. Os Anféhh. ne são a tribo bravia mais próxima dos Chawiyána: distam dêstes cêrca de dois dias de viagem. Ao redor de suas casas fincam paus (de pachiuba?) como defesa contra ataques inimigos (paliçada?, armadilhas de pau?). Possivelmente não sejam Karíb.

6. (6) Anfíka: Êstes índios vivem no rumo do rio Uatumã. Conta-se que são muito primitivos e que não formam aldeias, vagando em pequenos grupos por aquela zona. Parece, todavia, que já possuem arco e flecha. São muito temidos. Diz-se que, por ocasião de seus ataques, se transformam em onças bravias.

7. (7) Animpokóimo: Temivel tribo da região situada entre o Nhamundá e o Uatumã. Faltam maiores detalhes.

8. (8) Aparaí: Além dos Aparaí pacíficos do Paru-Maecuru, existem alguns grupos bravios desta tribo. Nomes especiais para êsses não me foram, no entanto, indicados. Vivem principalmente nas zonas intermediárias do Paru-Jari e Paru-Maecuru. Pelas informações dos Apa- 
raí, percebe-se que há contactos ocasionais com êsses grupos bravios. A tradição dos Aparaí narra o seguinte: "Antigamente, há muito, muito tempo, também os Aparaí bravios moravam nas margens do Paru e eram "mansos". Vieram então os "antigos dos brancos" (os conquistadores portuguêses do tempo colonial?), pegaram-nos, levaram-nos, pregaramnos pelas mãos e pelos pés nos esteios da casa e violentaram ou carregaram suas mulheres. Isto se repetiu algumas vêzes. Então êles se tornaram ferozes, vingaram-se, retiraram-se para as matas e até hoje não querem mais saber dos "Karaíwa" (brancos, civilizados)". Meu informante já havia se encontrado algumas vêzes com êles.

9. (12) Ataráu: Tribo localizada entre o Jatapu e o Wíni. Parece que outrora os Chawíyana tiveram contacto com êles. Dizem que éles se aculturaram parcialmente às tribos Parukotó, embora tenham permanecido relativamente intolerantes a qualquer visita de forasteiros.

10. (15) Atúma: São famosos pela sua ferocidade e perfídia. Moram no rio de igual nome, no Estado do Amazonas: Atuma ou Uatumã. Evidentemente não estão em estado muito primitivo, mas - conforme se diz - ainda são antropófagos e visam particularmente os caboclos e outros "civilizados". Com demonstrações de amizade, atraem à margem as canoas que passam, para assim poderem flechar de modo mais certeiro as suas vítimas.

11. (16) Awásene: Conta-se que ainda são autênticos selvagens com cultura tipicamente marginal. Não possuem instrumentos de ferro, nem arcos, nem flechas; sòmente artefatos líticos e, como arma para matar, usam cacêtes toscos ao invés de bordunas. Também não fazem roçados. Sendo exclusivamente caçadores e coletores, cercam a caça, na ocasião em que o animal vai comer, pegam-no de preferência vivo e comem sua carne sem cozinhá-la ou moqueá-la. Andam inteiramente nus. São tidos como ferozes e são temidos. Só atacam no escuro. São sempre mencionados juntamente com os Yáiheyána, dos quais se diz, em essência, a mesma coisa. (Ver n. ${ }^{\circ} 33$ ). E' provável que se trate de duas tribos aparentadas ou de dois grupos da mesma tribo. Seu "habitat" se localiza nos campos do alto Nhamundá.

12. (20) Chichayákere: Também moram na região campestre do alto Nhamundá. São temíveis e ferozes. Diz-se que são caçadores e coletores, mas não agricultores, faltando-lhes roças e plantações de qualquer espécie. (Serão um grupo aparentado aos Awásene?).

13. (27) Hichko-imó: Tribo das cabeceiras do Nhamundá ao que parece ainda na idade da pedra. Diz-se dêles o mesmo que dos Honikoimó: que são antropófagos etc. (Ver n. ${ }^{\circ} 14$ ). 
14. (28) Honiko-imó: Ainda não possuem instrumentos de ferro. Conta-se que são antropófagos ainda com cultura lítica. Receberam esta denominação devido às escavações que fazem por ocasião dos ataques, quando, à noite, cavam ao redor das raízes das grandes árvores, fazendo com que os troncos caiam em cima da maloca, matando seus moradores. Donde seu nome, que significa, literalmente, "porcos grandes da mata", mas cujo sentido é: "cavadores", ou melhor, "índios fossadores". São sempre mencionados juntamente com os Hichko-imó (Ver 11. ${ }^{\circ}$ 13). Talvez sejam dois grupos da mesma tribo ou, pelo menos, aparentados.

15. (40) Karaháuyana: Tribo temível da região do Wíni. Êsses indios, porém, já possuem bens culturais Karíb: casa redonda, arco, flecha etc. Os Chawiyána informaram que a cultura dêles $́$

à sua. Outrora os Karaháuyana viviam em conflito com os Amánarawá. As brigas constantes devem ter sido a causa do enfraquecimento ou extinção dessas tribos. Em vista da existência de uma tribo de igual denominação e de igual cultura na região do alto Turúnu, talvez se possa concluir tratar-se de uma tribo muito fragmentada que se estende por tôda a zona equatorial do Nhamundá ao Turúnu. Ambas as tribos pertencem também ao mesmo grupo dialetal: Parukotó-Charúma.

16. (42) Karáh.yana: Segundo algumas informações, já são extintos; segundo outras, ainda existem alguns remanescentes na zona intermediária do Nhamundá e Jatapu. Diz-se que eram muito ferozes e belicosos. Talvez se trate de um grupo dos Karahá ou Karaháuyana.

17. (44)Karará ou Kararáyana: Diz-se que são mais ou menos aculturados às tribos vizinhas, mas, mesmo assim, ainda um tanto ferozes. Moram na região intermediária de Wíni e Jatapu, fazem pequenas plantações, mas usam sòmente artefatos líticos e rejeitam instrumentos de ferro. Andam nus, são de tez clara e usam barba.

18. (62) Marácha: Vivem no ângulo formado pelo Nhamundá e Wíni. Contam os Chawiyána que êles ainda vivem na idade da pedra e não possuem instrumentos de ferro; que são ferozes e temidos, praticando a antropof gia, e que, de preferência, fumam o carvão ou a cin$z a$, bem socados, dos ossos de suas vítimas humanas.

19. (71) Mohéyana: Tribo do alto Acapu. Conta-se que ainda são bastante primitivos, que caçam e abatem a prêsa munidos de simples cacêtes. São rejeitados pelos Waríkyana como não pertencentes ao seu grupc.

20. (78) Páchkiyana: Vivem a oeste do Paru-Chitaré, e, ao que parece, são uma tribo bastante forte, feroz e belicosa, com elementos cul- 
turais da idade da pedra. Segundo as informações, especialmente dos Aparaí, trata-se de um grupo selvagem dos Wáyana. Dizem que a língua falada peîs Páchkiyána é idêntica à dos Wáyana. Êsses, porém, não gostam de abordar êste tema.

21. (85) Puchúma: Tribo do Jatapu-Uatumã. Faltam-me pormenores a respeito.

22. (86-87) Pianoí, Pianoisí, Pianosirít: Provàvelmente sejam os mesmos; habitam também a mesma área: o rio Chitaré. Parece que possuem muitas malocas. Já abandonaram, até certo ponto, a sua cultura primitiva, lítica, e já possuem tecelagem, plantações etc. Nas nascentes do Chitaré, têm contacto com os Aramihh.tchó, os Arámayána ou Arámagóto, que ficam mais a oeste. Uma informação dos Aramihh.tchó deixa entrever que os Pianoí pertencem aos Arámagóto. Assim, um dos meus companheiros de viagem, o velho Yamánta, que conheci em 1950 como chefe de sipe dos Arámayána e cujo retrato mostrei no Paru de Leste, foi identificado pelos Aramihh.tchó como sendo Pianoí. Êsses vivem em constante inimizade com os Wáyana. Por volta de 1954, um parente próximo de Aráipa, um dos meus informantes, foi assassinado nas proximidades da sua maloca. Encontraram-no morto; a cabeça e as costelas estavam quebradas e o cadáver se achava coberto de ferimentos profundos que pareciam causados por canivete. Tinham também cortado e levado a ponta da língua para provar a morte do homem, segundo á opinião de Aráipa. Outros, porém, afirmem que os Pianoí comem a ponta da língua, pois em todos os assassinatos até então ocorridos sempre se verificou que a ponta da língua da vítima havia sido cortada. Ao que parece, trata-se de um costume. Dizem os Wáyana que os Pianoí têm pés grandes. Por ocasião de um ataque, mataram um Pianoí e observaram que os dedos do pé da vítima eram ligados entre si por membranas compridas e estreitas (à semelhança das aves aquáticas).

23. (97) Rêpêworiworimó: Tribo feroz e belicosa, localizada entre o Jatapu e o Uatumã. De vez em quando, aparecem também no Nhamundá. Contaram-me apenas que andavam completamente nus e tinham tido freqüentes brigas com os Chawiyána e os Hichkaruyána.

24. (101) Seribá ou Seribáime: Dizem que hoje são extintos, mas que eram uma tribo selvagem, a oeste do Nhamundá. Contaram-me apenas que andavam completamente nus e que outrora tiveram freqüentes lutas com os Chaviyána e os Hichkaruyána.

25. (102) Taripiyó: Vivem no recôncavo da serra de Tumucumaque e atualmente não passam de um pequeno grupo. Embora estejam cercados por grupos Tiriyó, não são Tiriyó. Primitivos, possuem cultura lítica. Os Tiriyó chamam-nos, categòricamente, de "Kaikuí". An- 
dam nus. (Os Wáyana declaram que os Taripiyó também são Tiriyó selvagens, o que, como já foi dito, é negado, enèrgicamente, por êsses).

26. (104) Tchágoyána: Deve ser uma tribo muito primitiva porque, segundo as informações, caçam exclusivamente com cacête e ainđa não conhecem o arco e a flecha. A julgar pelos informes dos Kachúyana, os Tchágoyána não pertencem ao grupo dos Warikyana. Diz-se, porém, que são homens altos, com penas compridas e finas, assemelhando-se a uma saracura (ave aquática). Donde seu nome, um apelido, como se vê: Tchágoyána $=$ Indios Saracura.

27. (117) Tiriyómetésem: Grupo dos Tiriyó, da região do Itani, no rio Kuruwíni. Vivem em condições culturais da idade da pedra. São \{idos, entre os próprios Tiriyó, como bravios e foram indicados como parentes próximos dos Wayarikuré, mas são rigorosamente distinguidos por êles.

28. (118) Totó: Tribo belicosa localizada entre o Jatapu e o Uatumã. Faltam notas pormenorizadas a seu respeito.

29. (119) Totó-imó: Nome coletivo de vários grupos de tribos bravias que habitam entre o Mapuera e o Nhamundá. Sua lingua é Parukotó. Um dos seus centros de concentração são as nascentes do Ipitinga. De vez em quando, porém, chegam até o Nhamundá. Caminhos dêsses índios foram encontrados na cachoeira Carneiro (estreito do Nhamundá) e nas serras do lado esquerdo da cachoeira Fumaça. Outrossim, nas serras além da maloca Mutum. Ocasionalmente, vêm até as roças dos Hichkaruyána, onde já foram encontrados seus rastros. Seus caminhos são identificáveis por galhos e ramos de arbustos quebrados. O nome Totó-imó significa literalmente: homens fortes, homens altos, $€$ é também usado como sinônimo de "inimigos". Dizem que são de estatura muito maior que a do índio em geral e que são muito mais fortes. São notórios especialmente pelos pés, que são muito grandes. Rastros encontrados mediam 30-35 cm (medida tirada pelos índios com o auxílio de um peuzinho). Referem, também, que a forma do pé, à altura dos dedos - que são curtos - é muito larga e vai afinando para o calcanhar, quase pontudo. Asseguraram-me os informantes que os referidos rastros não eram de animal e sim humanos. A arma predileta dos 'Totó-imó é o cacête comprido, muitas vêzes enfeitado de penas e ponteagudo na parte inferior. Com êle, o adversário é primeiramente abatido e, em seguida, perfurado. Contam os índios que para perfurar o corpo humano, os três lugares preferidos são o pescoço (carótida), o coração e o ânus .

$\mathrm{Na}$ proximidade da maloca Mutum, dos Hichkaruyána, os Totóimó foram vistos, certa vez, caminhando pela mata, a passos largos de 
quase 1 (um) metro. Acham-se em estado de lenta aculturação às tribos vizinhas e quase todos já possuem facas, miçangas e tangas, que outrora não tinham. Seus mediadores são os Totókumu ou os Katuêma mansos do Acari. Uma peculiaridade foi ainda mencionada: muitas vêzes os Totó-imó cavam buracos no chão, tanto em plena mata como nas plantações dos Hichkaruyána, que disseram desconhecer a finalidade dessa prática. (Armadilhas para a caça? Infelizmente não conheço o tipo dêsses "buracos").

Visto o vocábulo Totó-imó também ser empregado no sentido de "inimigos", às vêzes as tribos bravias do alto Nhamundá-Jatapu são designadas com êsse nome, como os Anfehh. ne, Kararáyana etc.

30. (126) Waihayána: Tribo bravia e primitiva do alto Acapu. Sua arma exclusiva é o cacête, do qual se deriva seu nome: "Índios Cacête" (Waihá é o cacête curto dos Kachúyana). Caçam apenas com essa arma, sem arco è flecha. Não praticam agricultura. Os vizinhos Kachúyana rejeitam-nos como não pertencentes a seu grupo.

31. (128) Wáma: São tidos como ferozes e perigosos, e localizam-se entre o Paruma (Paloemeu) e o Itani. O grupo principal segundo os Tiriyó - moram nos igarapés do Urumari (Oelemari). Os Tiriyó reconhecem-nos como pertencentes a seu grupo. (Note-se que - vocabulário Wáma, editado por De Goeje, é Tiriyó legítimo, como o ouvi entre os Prôuyana). Parece que os Aramihh. tchó mantêm contacto com êles, pois disseram: "E', os Wáma são ferozes ("oide"), mas com a gente são não-ferozes ("oideta", isto é, bons)".

32. (130) Wari: Considerados hoje extintos, continuam, todavia, a figurar na tradição indígena como antigo povo guerreiro. Era uma tribo primitiva, outrora muito temida, da zona encachoeirada do Nhamundá. Possivelmente sejam os próprios Taguari (= Tawari) do Nhaw mundá, citados em documentos antigos.

33. (137) Wayarikuré: São mais conhecidos sob o nome de Oyarikulets. Pertencem às tribos bravias dos Tiriyó e repudiam qualquer contacto com estranhos. A maior parte da tribo mora em território brasileiro, especialmente nas regiões do Matáwari, formador da margem esquerda do rio Paru de Leste. Dizem que ainda são muito numerosos ("muito" entre os índios, porém, é um conceito bastante vago e começa com o número 4!). Evidentemente há encontros fortúitos dos Wayarikuré com os Wáyana, que hoje moram mais perto dêles que os TiriyóAramihh.tchó, seus parentes próximos. Os Wayarikuré são descritos como tendo tez clara. (Isto não é de admirar, pois que um dos tipos básicos do povo Tiriyó é esbelto e de pele clara). Segundo a informação geral, ainda são primitivos, de cultura marginal e lítica, sem agricultu- 
ra, tecelagem ou cerâmica. Desconhecem cordas de algodão ou mesmo de curauá. (De que então é feita a corda de seus arcos? De cipó? Pois, tanto quanto eu saiba, tendões de animais não são utilizados para êsse fim entre êsses povos). Por isso, também lhes faltam rédes; dormem no chão, sôbre esteiras de casca de árvore bem batida. Possuem, porém, arcos grandes e fortes, que são aplainados com a prêsa (ou queixada) do porco do mato. Usam também flechas de madeira com pontas de osso. Os instrumentos de trabalho consistem, quase que exclusivamente, em artefatos de pedra: machados, raspadores, batedores, lascas de quartzo etc. Utilizam como instrumentos ossos, madeira, conchas, como, por exemplo, a já mencionada queixada de porco empregada como plaina; dentes de cotia como faca e riscador etc. Os homens en. vergam, à guisa de tanga, palhas de palmeira curauá, e as mulheres, casca de madeira bem desfiada e macia. Consta que seu alimento principal consiste em raízes de palmeira murumuru, machucadas e raladas em pedras ásperas, ao que anexam pequenos invertebrados: moluscos, lagartas, tapurus e insetos. Possuem vários "patá", malocas ou aldeias, com "pakoró-monó", isto é, grandes casas de oitão (provàvelmente grandes casas comunitárias), mas desconhecem casas redondas. Parece, pois, que sua organização social é um tanto diferente da dos Tiriyó, já mais pacíficos e aculturados. Tapiris e abrigos contra as intempéries são feitos de galhos quebrados, sem sistema próprio de construção (?). Já se falou a respeito da sua aversão a qualquer contacto com os negros das Guianas, e é esta a razão por que lhes faltam instrumentos de ferro, fazendas, miçangas etc.

E' de notar a referência constante a seus arcos grandes e grossos, que, segundo as informações, atingem mais de 2 metros de comprimento. Para atirar, colocam o arco em posição vertical, fincam levemente a sua extremidade inferior no chão e seguram-na com o pé esquerdo (segundo a descrição dos Tiriyó) .

Certa vez, relatei o fato aos Kachuyána, que fizeram uma observação bastante esclarecedora sôbre o assunto: "Êsses índios devem morar nos campos onde há espaço suficiente para arcos assim compridos. Para nós, aqui na mata, tais arcos não seriem práticos. A tôda hora ficariam emaranhados nos galhos e arbustos e também não se poderia distender bem o arco. Ademais, o modo de fincá-los em pé, não seria vantajoso para nós, pois a caça muda constantemente de rumo e se esconde por detrás de moitas e troncos. Por isso, nós usamos arcos pequenos e cômodos, que se pode levar na mão e com os quais se pode correr com facilidade pela mata".

Em resumo: em campo aberto, o arco não precisa ser tão cômodo, mas em compensação deve ser mais forte e ter maior alcance, por- 
que a estepe oferece muito menor possibilidade que a mata para o indio se aproximar da caça.

$\mathrm{Na}$ realidade porém, os Wayaríkuré vivem numa zona quase exclusivamente de mata. Se existem campos por lá (fato que os índios do Paru negam), tratar-se-à apenas de pequenos espaços sem importância. Coloca-se, então, o problema: seria êste tipo de arco uma sobrevivência cultural de antigas tribos dos campos? Teriam os antepassados dos Wayaríkuré morado em zonas de campo? O tamanho extraordinário dos arcos dêstes índios, pertencentes ao grupo Tiriyó, causa ainda maior estranheza quando se considera que os próprios Tiriyó usam apenas arcos de tamanho médio (1,70-1,80m).

Segundo as informações dos Tiriyó, os Wayarikuré e os Tiriyómetesem não são os mesmos. Constituem, por assim dizer, tribos-irmãs: ambas são grupos bravios dos Tiriyó, mas bem distintas uma da outra.

34. (142) Yáiheyána: São selvagens primitivos dos campos do alto Nhamundá, quase sempre citados juntamente com os Awásene. Parece tratar-se de duas tribos intimamente aparentadas ou de grupos de uma mesma tribo. Seu nome "Índios Anta" é derivado da sua caça pre. dileta, que cercam, acossam, abatem e comem crua. Tôdas as outras notas colhidas sôbre êles coincidem com as que se referem aos Awásene (Ver n. ${ }^{\circ} 11$ ).

Além das tribos bravias discriminadas, existem, com certeza, outras que deveriam ser aqui incluídas. Assim, é provável que existem ainda grupos primitivos nas regiões das nascentes do Kafuíne, Turúnu e Kotonúru, dos quais não pude obter nem nomes nem particularidades, a não ser referências às suas "estradas quebradas à mão" e a seus primitivos instrumentos líticos. Também das tribos não classificadas, registradas no mapa anexo, algumas, sem dúvida, deverão ser consideradas como ainda bravias ou como grupos incipientemente aculturados aos Karíb, como p. ex. os Rêrêyána do Kurátari-Kachpakúru (que, segundo os Kachúyana, são antropófagos semi-bravios), e talvez, os Ororikó, Itúyana etc., do Alto Kotonúru, bem como os Mureyána e os Kurúmuyána da região do Paru de Leste. Faltam, porém, informações mais precisas para tal inclusão, motivo pelo qual os excluí dêste resumo.

\section{VII - Registro das tribos}

As denominações tribais, colhidas no decorrer dos anos, foram aqui compiladas em ordem alfabética. O registro abrange tanto as designações grupais e os nomes individuais das tribos, como os de subtribos ou sipes que me foi dado conhecer, pois estas últimas também constituem unidades sociais ou grupos locais. Para dar uniformidade ao trabalho, foi organizado o esquema que se segue, muito embora nem sempre tivesse sido possivel preencher todos os seus itens: 
N. ${ }^{\circ}$ Denominação da tribo.

a) Variantes e sinônimos da denominação.

b) Explicação e sentido Jo nome.

c) Grupo lingüístico e cultural.

d) Grupo dialetal.

e) Local ou área de residência.

f) População.

g) Traços gerais de caráter, segundo a opinião dos informantes indígenas sôbre tribos vizinhas.

h) Informações. Informantes.

i) Ligeiras notas sôbre visitas às tribos; peculiaridades referentes a grupos não visitados etc. (As observações relativas aos grupos bravios ou marginais estão assinaladas com o número do capítulo sôbre as tribos bravias, isto é, Cap. VI).

1. Achikí (índios do)

a) O nome próprio é desconhecido.

b) ?

c) ?

d) ?

e) No rio Achikí, afluente da margem direita do Paru

f) ? de Leste, um pouco abaixo do Chitaré.

g) Desconfiados e bravios.

h) Wáyana.

i) Ver VI, n. 1.

2. Akuriyó
a) -
b) Indios Cutia. E' denominação Tiriyó (akuri = cutia; yó $=$ povo .
c) Karíb.
d) Pianokotó-Tiriyó.
e) No rio Tapái, entre o Paruma (Paloemeu) e Tapa- nani (Tapanahoni), Suriname.
f) Várias malocas.
g) Bravios e antropófagos.
h) Tiriyó: Prôuyana, Arámayana, Aramihh.tchó.
i) Ver VI, n. ${ }^{\circ} 2$.

3. Amanarawá
a) -
b) ?
c) ?
d) ?
e) Outrora entre o Wíni e o Nhamundá.
f) Extintos (?).
g) Muito belicosos. 
h) Hichkaruyána, Chawiyána.

i) Ver VI, n. ${ }^{\circ} 3$.

4. Amúimo
a) -
b) ?
c) ?
d) ?
e) Cabeceiras do Nhamundá.
f) ?
g) Bravios.
h) Hichkaruyána, Chawiyána.
i) Ver VI, $\mathrm{n} .{ }^{\circ} 4$.

5. Anféhh.ne
a) -
b) ?
c) ?
d) ?
e) Num pequeno afluente do Jatapu, na altura do Wíni.
f) Parece que só possuem 2 ou 3 malocas.
g) Bravios e temíveis.
h) Hichkaruyána, Chawiyána.
i) Ver VI, n。․ 5 .

6. Anfíka
a) -
b) ?
c) ?
d) ?
e) No rio Máze, afluente do Uatumã, na zona interme- ?
g) Muito ferozes e agressivos.
h) Chawiyána.
i) Ver VI, n. 6 .

7. Animpokóimo
a) -
b) ?
c) ?
d) ?
e) No curso superior do Nhamundá, Jatapu e Uatumã
f) Várias malocas.
g) Bravios e temíveis.
h) Hichkaruyána, Chawiyána.
i) Ver VI, $2 .{ }^{\circ} 7$.

8. Ápama
b) ?
c) Tupi (tupinizados?). 
d) (Lingua geral?) .

e) Num afluente da margem esquerda do Maecuru, en trezona de Maecuru-Paru.

f) Sòmente uma pequena maloca.

g) Ao que parece, bons e pacíficos.

h) Aparaí.

i) Segundo algumas informações dos Aparaí, os Ápama já desapareceram; segundo outras, existe ainda uma maloca. Também Pr. Alberto Kruse, ofm., em 1944 ouviu falar da existência de um grupo Ápama remanescente. Os seus informantes foram os Aparaí do Maecuru.

9. Aparaí

a) Entre os Tiriyó: Aparaí, também Apalái.

b) Provàvelmente: "arcos pequenos" (adoção do Tupí ou da língua geral).

c) Karíb.

d) Grupo dialetal Karíb (do ponto de vista da cultura, porém, estreitamente ligados aos Wáyana).

e) Ao norte do equador, nos rios Paru de Leste, Jari, Maecuru e Curuá de Alenquer.

f) Total: 200-300 almas.

g) Muito pacíficos; gostam de negociar.

h) Aparaí, Wáyana, Tiriyó.

i) Visitados em 1955 no Paru. (A respeito de grupos Aparai bravios, ver VI, n. ${ }^{\circ} 8$ ) .

10. Arámayana

a) Entre os Tiriyó são chamados Arámayana; entre os Aparaí e Wáyana: Aramagotó, Aramakotó.

b) Indios Abelha Preta (Tiriyó: arama = abelha preta).

c) Karíb.

d) Pianokotó-Tiriyó.

e) Paru de Oeste, Irikí e a zona dos campos até o Chitaré.

f) .6 malocas, pelo menos, com cêrca de 150 almas.

g) No Paru de Oeste: mais ou menos pacíficos.

h) Tiriyó, Aparaí, Wáyana, Aramihh.tchó .

i) Visitados em 1950 e 1952 no Paru de Oeste. São uma sub-tribo dos Tiriyó; possivelmente os Pianoí e Pianosiri sejam grupos bravios dos Aramagotó. Seu apelido deriva da côr de sua pele, um pouco mais escura.

11. Aramihh.tchó

a) Aramichó; Aramisó.

b) Indios Pombo (Tiriyó: arami $=$ pombo esp.).

c) Karíb.

d) Pianokotó Tiriyó.

e) No Okômôkê (alto Paru de Leste), Arakopina e nos campos à direita do Okômôkê.

f) 3 malocas com mais ou menos 100 almas. 
g) Pacíficos.

h) Aramihh.tchó, Prôuyana, Aramayána, Wáyana.

i) Visitado em 1955 no Okômôkê e Arakopina. Sua cultura ainda conserva certo número de elementos líticos, embora a olaria, a tecelagem etc. já tenham tido acesso a êles. São uma subtribo Tiriyó.

12. Araráu
a) -
b) ? (Arara $=$ arara azul).
c) ?
d) ?
e) Alto Jatapu.
f) ?
g) Bravios .
h) Chawiyána.
i) Ver VI, n. 9 .

13. Arawahô
a) -
b) ?
c) ?
d) ?
e) Outrora no interior do Caipuru (zona do baixo Trom.
f) ?
g) ?
h) Kachúyana.
i) Dizem que eram anões. Indicaram-me que sua al- tura era de menos de $1,50 \mathrm{~m}$. Talvez tenham sido uma tribo marginal; se moravam no Caípuru, atual- mente ou são ignorados ou emigrados ou extintos.

14. Arimihotó
a) Entre os Aparaí e Wáyana: Arimiyána.
b) Indios Coatá (arimi = coatá).
c) Karíb.
d) Pianokotó-Tiriyó.
e) No Kuruni (Suriname), Cuxaré (Brasil) e Paruma (Suriname).
f) 3-4 malocas, com cêrca de 100-120 almas.
g) Um pouco desconfiados, porém pacíficos.
h) Tiriyó: Prôuyána, Okômoyána, Arimiyána.
i) Visitados em 1952. São um subgrupo dos Tiriyó.

15. Atúma
a) -
b) ?
c) ?
d) ?
e) No rio Atuma ou Uatumã (Estado do Amazonas).
f) ? 
g) Bravios, agressivos, traiçoeiros.

h) Tchawiyána.

i) Ver VI, n. ${ }^{\circ} 10$.

16. Awásene
a) -
b) ?
c) ?
d) ?
e) Na zona dos campos, acima do Nhamundá.
f) ?
g) Selvagens, temíveis .
h) Chawiyána, Hichkaruyána.
i) Ver VI, n. ${ }^{\circ} 11$.

17. Awi
a) -
b) ?
c) Karib.
d) Parukotó-Charúma.
e) No Turúnu (outrora também no Panamá?).
f) Ao que parece, uma só maloca.
g) Mais ou menos pacíficos.
h) Tiriyó; Charúma do Panamá.
i) São conhecidos entre os Marah.tchó como bons fa- bricantes de arcos.

18. Charúma

Entre os Tiriyó, a denominação é usada como nome coletivo para as tribos do rio Turúnu. Segundo o índio Charúma Konokonó, o grupo todo deveria abranger mais ou menos 15 subtribos. Juntamente com as tribos Parukotó do MapueraNhamundá, formam um grupo dialetal uniforme.

Como pertencendo, com certeza, às tribos Charúma, foram-me indicados:

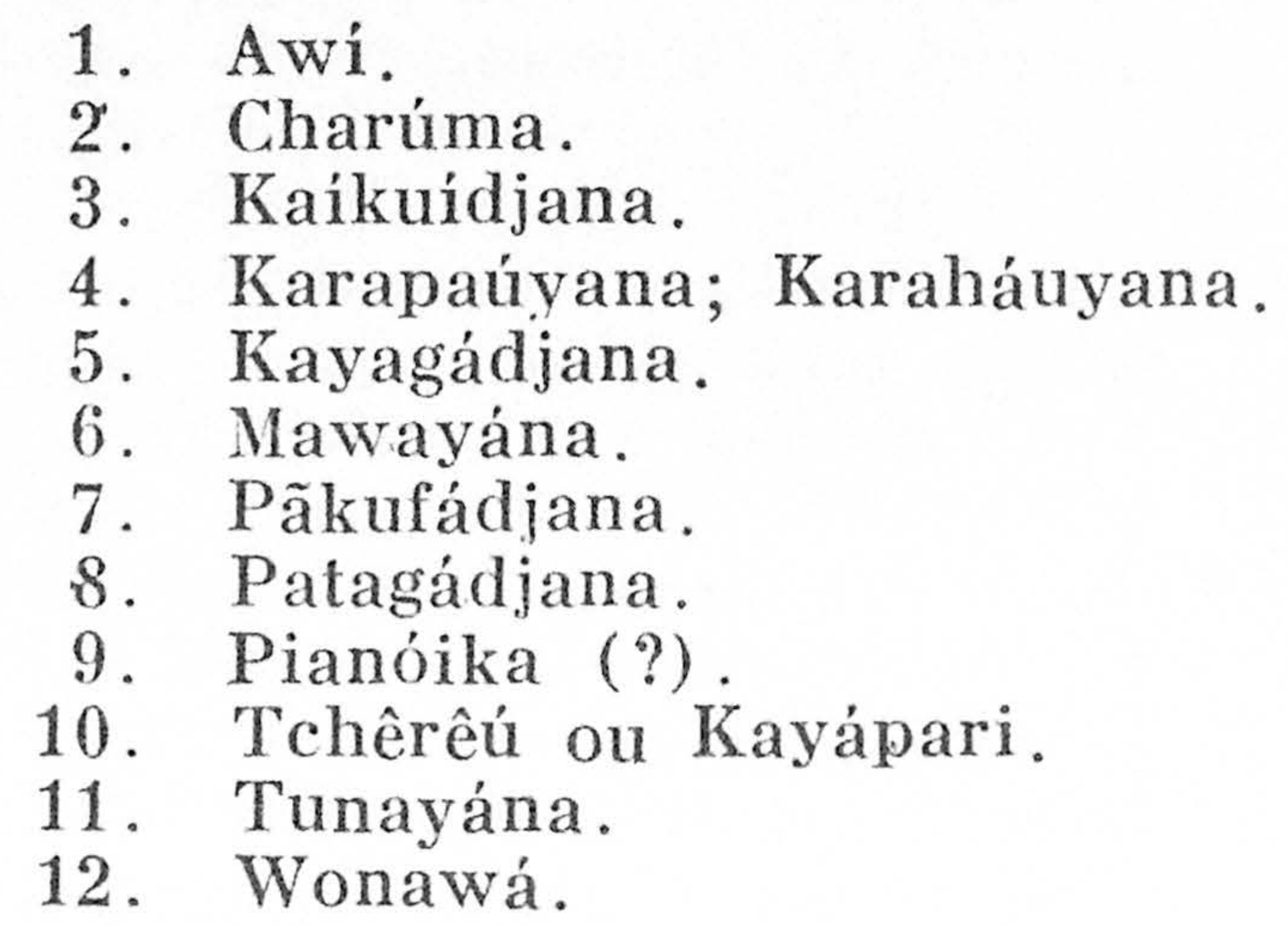

19. Charúma
a) Tcharúma; Tsarúma; entre os Aparaí e Wáyana: Sa- rúma, Salúma.
b) ? 
c) Karíb.

d) Parukotó-Charúma.

e) Nas regióes da margem esquerda do rio Turúnu.

f) Mais ou menos 3 ou 4 malocas.

g) Bons e pacíficos; muito propensos ao comércio.

h) Charúma, Tiriyó, Marah.tchó, Aparai, Wáyana, Kachuyána.

i) Em 1953, tive um encontro com índios dêsse grupo, no Trombetas-Panamá. Entre os Tiriyó, todo o grande grupo das tribos do Turúnu é designado por "Charúma", devido aos Charúma pròpriamente ditos.

20. Chichayákere
a) Tchitchayákere; Chitchayákere.
b) ?
c) ?
d) ?
e) Na zona dos campos do alto Nhamundá.
f) ?
g) Temiveis pela selvageria.
h) Chawiyána.
i) Ver VI, $n *^{\circ} 12$.

21. Chiriwiyána
a) Tchiriwiyána.
b) ?
c) Karíb.
d) Parukotó-Charúma
e) No rio Acari, entre o Nhamundá e Mapuera.
f) 3 ou 4 malocas.
g) Mais ou menos pacíficos.
h) Chawiyána, Hichkaruyána, Kumiyána, Chiriwiyána.
i) Em 1955, tive um encontro com alguns dêstes indios no Nhamundá. São aparentados com os Kúmiyána e, em parte também, com os Chawiyána, devido aos in- tercasamentos. Pertencem aos chamados Katuêma mansos ou Totókumu.

22. Ewarhoyána
a) -
b) Indios Anta (Kachúyana: ewarho = anta).
c) ?
d) ?
e) No rio Kotonúru.
f) ?
g) Bravios e maus.
h) Kachúyana.
i) Possivelmente ainda um grupo bravio ou marginal.

23. Ewarhoyána 
c) Karib.

d) Waríkyana.

e) Do igarapé da Anta, afluente da margem esquerda do Kurátari, até o Marapi, na zona dos campos, pois

f) ? fala-se dos "campos dos Ewarhoyána".

g) Ao que parece, ainda um tanto selvagens.

h) Kachúyana.

i) Não confundir com os Ewarhoyána do Kotonúru ou os índios Anta (Maipurípjana) dos Tiriyó.

24. Faranakarú
a) Também no Nhamundá: Faranakáre.
b) Indios Tucunaré (entre as tribos Parukotó: fara- ná, haraná $=$ peixe tucunaré) .
c) Karíb.
d) Parukotó .
e) No alto Tutúmu, até o Nhamundá.
f) ?
g) Ao que consta, bons e pacíficos.
h) Faruarú, Hichkaruyána, Chawiyána, Parukotó.
i) Em 1949 tive um encontro com alguns dêles no Ta- wíni. São de côr bastante escura e traços fisio- nômicos um tanto grosseiros. Já em 1727 foram mencionados por Frei Francisco de São Marcos. Talvez sejam idênticos aos Mawarí.

25. Faruarú
a) Entre os Chawíyána e Hichkaruyána: Farukuotô, Parukotó.
b) ? (Ver o n. ${ }^{\circ} 81$, Parukotó).
c) Karíb.
d) Parukotó-Charúma.
e) No alto Mapuera: Tawíni, Tutúmu, Kumúnu, Bara- kuchí (Kikwó).
f) Cêrca de 6 ou 8 malocas.
g) Bons, agradáveis, pacíficos.
h) Faruarú, Kachúyana, Hichkaruyána.
i) Visitados em 1949. Errôneamente, são muitas vê- zes denominados, pelos habitantes do Trombetas, de "Pianokotó do Mapuera". Pelos Kachúyana é sem- pre mencionado o seu endocanibalismo. Bebem as cinzas dos ossos dos cadáveres cremados, mistura- das com bebidas. Segundo alusões indígenas, fa- zem isso "para se tornarem mais ferozes e fortes". Os ossos carbonizados são conservados em pequenas cestas no sótão das casas redondas.

26. Hichkaruyána
a) Hitchkaruyána.
b) Indios Veado Vermelho (tribos Parukotó: hichkaru
c) Karib. 
d) Parukotó-Charúma.

e) Nhamundá, acima da cachoeira da Fumaça, até a confluência com o Wíni.

f) 4 pequenas malocas com mais ou menos 80 almas.

g) Outrora, muito belicosos; hoje, bastante bons e pacificos.

h) Hichkaruyána, Chawiyána, Kumiána.

i) Visitados em 1951 e 1955.

27. Hichkó-imo
a) -
b) Jacamim Grande (ou gigante): hichko = jacamim; imo $=$ grande.
c) ?
d) ?
e) Nas cabeceiras do Nhamundá.
f) ?
g) Bravios, inimigos de todos.
h) Chawiyána.
i) Ver IV, n. ${ }^{\circ} 13$.

28. Honikó-imo
a) -
b) Porco Grande; Queixada Grande (tribos Parukotó:
honikó = queixada; porco do mato; imo = grande,
c) ?
d) ?
e) Nas cabeceiras do Nhamundá.
f) ?
g) Selvagens, geralmente temidos.
h) Chawiyána.
i) Ver VI, n. $\circ^{\circ} 14$.

29. Ingarüne
a) Inkarüne; Imkarüne. Entre os Tiriyó, Aparaí e Uru- kuyána também são chamados Tchikaridjana.
b) Incerta; mas se deriva, sem dúvida, de Karina = homem, indio etc.
c) Karíb.
d) Waríkyana.
e) Trombetas, Panamá, Ponékuru.
f) 2 ou 3 malocas. Mais ou menos $60-70$ almas.
g) Um tanto desconfiados; são considerados meio bons e meio selvagens.
h) Kachúyana, Ingarüne, Marah.tchó .
i) Visitados em 1953, no Panamá. Tive um encontro com o grupo do Ponékuru, no Trombetas, também em 1953. Tótome, no Panamá, é a sua última malo- ca. Outrora êles habitavam ao longo do Trombetas. Ao que parece, são essencialmente idênticos aos an- tigos Káh.yana (ou teriam sido simplesmente um subgrupo dêles?) Uma informação dos Kachúyana 
diz o seguinte: "Ingarüne veio de Paríkuru e, antigamente, era Parikotó". (Coloca-se o problema: Parikuru é $=$ Arikuru ou rio Amazonas e os antigos Parikotó teriam sido, igualmente, tribos do Amazonas?) .

30. Ichitchwáyana; Itchitchwáyana

E' o nome coletivo para o grupo dos Kachúyana que morava no Itchitchwáhô ou Igarapé do Ambrósio. $\mathrm{O}$ próprio nome o indica: habitantes, povo etc., do Itchitchwáhô. Para as demais anotações ver adiante n. 33 , Kachúyana.

31. Ituyana
a) -
b) Indios Guariba (Kachúyana: Itúri = guariba; yana
c) ?
d) ?
e) ?
f) ?
g) Bravios
h) Kachúyana .
i) Talvez se trate de uma tribo ainda selvagem. Se- gundo uma informação isolada, êles usam barba e, por isso, se parecem com os guaribas.

32. Kachpakúyana

O nome significa: moradores ou indios do rio Kachpakúru. E' um nome coletivo entre os Kachúyana para as tribos do Kachpakúru. Todavia, as mais das vêzes sòmente os Káh.yana são designados assim.

33. Kachúyana

a) Katchúyana; entre os Aparaí e Wáyana: Kasúyana.

b) Morador\$s do rio Kachúru. (Ver i).

c) Karib.

d) Warikyana.

e) Nos rios Cachorro, Cachorrinho, Ambrósio, Yaskuri e Trombetas, até mais ou menos a cachoeira da Fumaça (equador).

f) 4 ou 5 pequenas malocas, no máximo com 80 almas.

g) Muito pacíficos.

h) Kachúyana.

i) São descendentes dos antigos Warikyana ou Arikiêna, porém mesclados com tribos da Trombetânia ocidental. Têm freqüentes contactos com os civilizados. Visitei os, quase anualmente, de 1945 a 1950. O nome Kachúru é ininteligivel aos atuais Kachúyana e parece originado da antiga lingua dos Warikyana. Em mapas antigos o rio é denominado Kasúru. Entre os Aparaí, Kasúru quer dizer: contas, miçangas. Kasúru-tuna seria, portanto, o "rio das contas". Es- 
ta explicação correspondente à tradição indigena, segundo a qual dessa região provêm as antigas contas e "idolos" de pedra (Ver os "idolos" do rio Trombetas no Museu de Gotemburgo). A expressão portuguêsa rio Cachorro não é senão corruptela da indígena: Kachúru.

34. Káchwana
a) -
b) ?
c) ?
d) ?
e) No rio Maze, que corre na zona intermediária do Jatapu e Uatumã, sendo provàvelmente um afluen- te dêste último.
f) ?
g) Ao que parece, pacíficos.
h) Chawiyána.
i) Segundo as informações dos Chawiyána, são os vi- zinhos dos Anfika.

35. Kahúyana

O nome significa: habitantes do Trombetas. São o gru po dos Kachúyana que vive no Trombetas pròpriamente dito e que emigrou do rio Cachorro, há poucos decênios. Possuem sòmente 2 pequenas malocas com 30 indivíduos, no máximo, e se encontram em fase de desagregação. Pertencem aos Waríkyana. (Para tôdas as outras indicações ver $n .^{\circ} 33$, Kachúyana).

36. Káh.yana
a) São também denominados: Kachpakúyana. (Ver n. ${ }^{\circ} 32$ ).
b) Habitantes do Trombetas (contração de Kahú-yana, isto é, Kahú $=$ Trombetas; yana $=$ gente $)$.
c) Karíb.
d) Waríkyana.
e) Outrora, em todo o vale do Trombetas; hoje, sò- mente no Kachpakúru e Imno-húmu.
f) 2 malocas com 50 ou 60 almas.
g) Um tanto rudes e briguentos; muito desconfiados.
h) Kachuyána, Káh.yana.
i) Visitados em 1948 no rio Kachpakúru. Dizem que, primitivamente, eram Parukotó e Ingarüne. Por- tanto, provàvelmente sejam um pouco mesclados. Os antigos Káh.yana, devido às suas brigas, cons- tituiam outrora o pavor do Trombetas. (Algumas lendas guerreiras dos Káh.yana e Kachúyana foram publicadas em: "Tradições Histórico-Lendárias dos Kachúyana e Káh yana", Revista do Museu Paulista, Nova Série, Vul. 9, págs. 203 e segs., São Paulo) .


37. Kaikuidjana
a) -
b) Indios Jaguar (Kaikuí $=$ onça, jaguar; yana $=$ po- vo)
c) Karíb.
d) Parukotó-Charúma.
e) Do rio Turúnu até o rio Cachorro.
f) ?
g) Ao que parece, não são muito pacíficos.
h) Tiriyó, Marah.tchó, Prôuyana, Charúma.
i) Ver n. ${ }^{\circ} 38, \mathrm{i}$.

38. Kaikúts . yana
a) -
b) Indios Jaguar (têrmo Kachúyana: kaitsú = jaguar; yana $=$ povo $)$.
c) ? (Karib?)
d) ? (Parukotó-Charúma?).
e) No alto Kotonúru.
f) ?
g) Selvagens e desconfiados.
h) Kachúyana.
i) Provàvelmente idênticos aos Kaikuídjana do vizi- nho rio Turúnu. Sendo assim, pertenceriam ao gru- po Parukotó-Charúma.

39. Kamáreyana
a) -
b) Indios Jaguar (têrmo Parukotó: kamára = onça, jaguar, yana $=$ povo).
c) Karíb.
d) Parukotó-Charúma.
e) Outrora, espalhados entre o Nhamundá (cachoeira do Paraíso) e o Acari.
f) Pràticamente extintos; poucos remanescentes.
g) Outrora, muito ferozes e temidos; hoje, pacíficos.
h) Chawiyána, Hichkaruyána, Chiriwiyána, Kamá- reyana.
i) A tribo pràticamente já não existe mais, pois so- brevivem apenas alguns descendentes da linha femi- nina. O resto da tribo, segundo dizem, mesclou-se principalmente com ơs Hichkaruyána e foi por êles absorvido. Alguns indivíduos, que pelo lado mater- no ainda são Kamáreyana. na realidade não têm mais essa denominação, porque entre êles reina o regime da descendência patrikinear. Outrora os Kamáreyana eram temidos como guerreiros e antropófagos.

40. Karaháuyana
a) Indios Aracuã (?)
c) Provàvelmente Karíb. 
d) Talvez Parukotó-Charúma.

e) Nas cabeceiras do Wini, esperialmente no igarapé Tcharíri-oku.

f) ?

g) Bravios e muito temidos.

h) Chawiyána.

i) Ver VI, n. 15.

41. Karaháuyana

a) Karaháyana, Karafaúyana.

b) Indios Aracuã (?).

c) Karíb.

d) Parukotó-Charúma.

e) No alto Turúnu.

f) ?

g) Mais ou menos pacíficos.

h) Charúma; Tiriyó.

i) E' possível que êstes índios e os Karaháuyana da re gião do Nhamundá $\left(n^{\circ}{ }^{\circ} 40\right)$ sejam grupos isolados de uma só tribo. Os Tiriyó mencionaram na mesma área e com as mesmas indicações os Karapanaúyana (n." 43). Será outra denominação da mesma tribo?

42. Karáh.yana
a) -
b) Também Índios Aracuã (Karahá = aracuã).
c) Karíb
d) Provàvelmente Parukotó-Charúma.
e) Entre o Wíni e o Jatapu.
f) Segundo algumas informações estão extintos; segun- do outras, ainda existem alguns remanescentes.
g) Bravios, belicosos.
h) Chawiyána, Hichkaruyána.
i) Ver VI, n. ${ }^{\circ}$ 16. Possivelmente se trate de um grupo isolado dos Karaháuyana.

43. Karapanaúyana
a) -
b) ?
c) Karíb.
d) Parukotó-Charúma.
e) Na região do alto Turúnu.
f) ?
g) Mais ou menos pacificos.
h) Tiriyó Charúma, Marah.tchó.
i) Possivelmente sejam os mesmos Karaháuyana do Tu- rúnu (Ver n. $\left.{ }^{\circ} 41\right)$.

44. Karará
a) Kararáyana.
b) ?
c) ?
d) ? 
e) No alto Jatapu, para o lado do Wíni.

f) ?

g) Meio ferozes.

h) Chawiyána.

i) Ver VI, n. 17.

\&5. Karíana
a) Karíyana.
b) ?
c) ?
d) ?
e) No Kotonúru.
f) ?
g) Bravios.
h) Kachuyána.
i) Talvez ainda uma tribo de cultura marginal.

46. Karina
a) Kalina.
b) Homens, gente, índios (?) .
c) Karíb.
d) ?
e) No baixo Tapanani e zonas adjacentes; Ariminá, Ari- taní.
f) Várias malocas.
g) Ora bons, ora ruins.
h) Tiriyó, Prôuyana, Okômoyána.
i) Outrora os Tiriyó mantiveram estreito contacto com êles. Hoje são evitados; tornaram-se "narige" ou "tabu", porque se revelaram raptores de crianças.

47. Katuêma

Nome coletivo das tribos entre o Mapuera e o Nhamundá. O têrmo parece derivado da língua geral (do tempo das Missões?) e aparentemente significa "não bom", portanto: mau, ruim, selvagem. Os indios do Nhamundá distinguem entre "Katuêma mansos" e "Katuêma bravios". Os Katuêma mais pacificos também são chamados Totókumu (Ver n. ${ }^{\circ} 120$ ); os bravios: Totó-imó (Ver n. $\left.{ }^{\circ} 119\right)$.

48. Katuêma (mansos)
a) Totókumu
b) Primitivamente: os "não-bons", os maus, os ferozes.
c) Karib.
d) Parukotó-Charúma.
e) No Mapuera equatorial: Acari, Cachorrinho e até o Nhamundá.
f) Um total de 8 malocas.
g) Conhecidos como desconfiados e ainda meio bravios.
h) Chawiyána, Hichkaruyána, Katuêma.
i) Visitados em 1949 no Mapuera; outros, encontrados em 1955 no Nhamundá. Os Katuêma do Mapuera Ca- 
chorrinho, possivelmente sejam os mesmos Katwená dos Kachúyana. Esses "Katuêma mansos" abrangem principalmente as tribos Chiriwiyána e Kumiyána do Acari.

49. Katwená
a) -
b) ?
c) Karíb.
d) ? (Parukotó-Charúma?).
e) Rio Cachorrinho-Mapuera
f) ?
g) ?
h) Kachúyana.
i) Possivelmente idênticos ąos Katuêma da zona do Mapuera (Ver n. ${ }^{\circ} 48$ ).

50. Kayagádjana
a) -
b) ?
c) Karib.
d) ? (Parukotó-Charúma?).
e) Da região do Turúnu até o rio Cachorrinho.
f) ?
g) Mais ou menos pacíficos.
h) Tiriyó, Charúma.
i) -

51. Kayápari

Essa denominação é raras vêzes usada. São mais conhecidos por Tchêrêú (Ver n. ${ }^{\circ}$ 108).

52. Kotónúru (grupo de tribos do rio Kotonúru)

Parece que não se trata exclusivamente da região do Kotonúru, e sim, parcialmente, também da zona do Turúnu. O Kotonúru ainda é totalmente inexplorado. A classificação da maior parte dessas tribos fica em branco. A maioria dêsses indios provàvelmente ainda é selvagem e de cultura marginal. Segundo os Kachuyána, os índios do Kotonúru são "bichos" e "onças ferozes" e são apontados como guerreiros e assassinos audazes. A êles pertencem:
1. Ewarhoyána
2. Itúyana
3. Kaitútsyana
4. Karíana
5. Keháyana; Kuháyana
6. Mék.yana
7. Prôuyana
8. Tchiháyana
9. Tchurutáyana 
10. Wêyana

11. Woiremêyana

As informações são dos Kachúyána (Ver as anotações nos números respectivos).

53. Kraptê
a) -
b) ?
c) Karíb.
d) ?
e) No igarapé Awatsyáhô, afluente da margem direita do alto rio Cachorro.
f) Poucos individuos.
g) Dizem que são pacíficos.
h) Kachúyána.
i) Os Kachúyána antigamente tiveram contacto com
os Kraptê.

54. Kuhâyana
a) Keháyana.
b) Moradores do rio Pachiúba (Kuhá = palmeira pa- chiúba).
c) Karíb.
d) Provàvelmente Waríkyana.
e) Nas cabeceiras do rio Kihá, por cima do Kotonúru, até o rio Cachorrinho.
f) ?
g) Um tanto ferozes.
h) Kachúyana.
i) Como peculiaridades, conta-se que êsses índios usam tangas de pano e de miçangas, mas dormem comple- tamente nus.

55. Kuí

Tribo um tanto duvidosa. Ver Wayárama, n. ${ }^{\circ} 136$.

56. Kukuyána
a) -
b) ?
c) Karíb.
d) Pianokotó-Tiriyó.
e) Não bem localizados; ao que parece, na região ds Panamá-Marapi.
f) ?
g) Dizem que são perversos e selvagens; são acusados da quase completa extinção dos Okômoyana.
h) Tiriyó, Prôuyana, Okômoyana.
i) Provàvelmente um grupo de Marah.tchó em estado ainda semi-bravio.


57. Kúmiyána
a) -
b) ?
c) Karíb.
d) Parukotó-Charúma.
e) No rio Acari, cognominado pelos indios de Kãri, afluente equatorial do Mapuera-Nhamundá.
f) 2 ou 3 malocas.
g) Mais ou menos pacíficos.
h) Chawiyána: Hichkaruyána, Kúmiyána.
i) Tive um encontro, em 1951 e 1955, com alguns dê- les. Pertencem aos Totókumu ou' "Katuêma man- sos". São aparentados com os Chiriwiyana e for - necem, às tribos vizinhas, pontas de flechas de fer- ro, que fabricam de terçados recebidos das tribos do alto Mapuera.

58). Kúmuyana
a) -
b) Indios Bacaba; moradores do rio Bacaba (kúmu = bacaba) .
c) Karíb (?)
d) ? (Em todo caso, não são Tiriyó).
e) No curso superior do Kutári (afluente do Chipari- wini, Suriname).
f) 2 malocas .
g) Muito bons e comunicativos.
h) Tiriyó, Prôuyana, Okômoyana, Aramíhh.tchó.
i) São muito amigos dos Tiriyó, embora êstes digam, expressamente, que êles não são Tiriyó.

59. Kurúmuyana
a) -
b) Indios Urubu Rei.
c) ?
d) ?
e) Zona intermediária do Paru de Leste e Maecuru, mais ou menos entre 1 grau de latitude sul e o equador.
f) ?
g) ?
h) Aparaí, Wáyana.
i) Sempre citados juntamente com os Mureyána. Tal- vez se trate de índios ainda desconhecidos, das ca- beceiras dos igarapés Mariussú, Kapukú e Umara- tiá, afluente da margem direita do Paru.

60. Maipurídjana
a) -
b) Indios Anta (Maipurí = anta).
c) Karíb.
d) Pianokotó-Tiriyó. 
e) Na bacia do Chipariwini; segundo outras informações, também no Panamá.

f) Grupo já pouco numeroso.

g) Pacíficos.

h) Tiriyó : Prôuyana, Okômoyana.

i) Pertencem ao grupo dos Okômoyana. Devido ao reduzido número de famílias, moram dispersos entre outros grupos Tiriyó, especialmente entre os Prôu yana.

61. Makuchí

a) Makúchi; Makútchi; Makúdji .

b) ?

c) Karíb.

d) ? (Parukotó?).

e) No Kumúnu, até o rio Branco e a Guiana Inglêsa.

f) Na região do Tawini, muito fraca.

g) Bons, pacíficos.

h) Faruarú, Chawiyána.

i) Encontrados no Tawini, em 1949. Dizem os Chawiyána que sua língua é quase idêntica à dos Makuchí, que apenas existem pequenas diferenças e que, por ocasião de encontros fortúitos, sempre se compreenderam bem. Não conheço bastante o dialeto Makuchí para afirmar se êle pode ser agregado ao grupo Parukotó. A pequena lista de vocábulos que pude colher, revela muitas semelhanças, mas também certo número de divergências.

62. Marácha

b) ?

c) ?

d) ?

e) No ângulo dos rios Wíni e Nhamundá.

f) ?

g) Bravios

h) Chawiyána.

i) Ver VI, n. 18 .

63. Marah.tchó

a) Mara/chó; Maradjó; entre os Kachuyána também: Marajó.

b) Indios Jacu (?) (Mara, marachi $=$ jacu; yó, jó, chó etc. $=$ gente, povo, tribo etc.).

c) Karíb.

d) Pianokotó-Tiriyó.

e) No Panamá e Marapi, até as cabeceiras do Kachpakúru.

f) Um total de 13 ou 15 malocas.

g) Um tanto desconfiados, mas pacíficos; outros os dão como ferozes.

h) Tôdas as tribos Tiriyó, Kachúyana, Charúma. 
i) Visitados no Panamá, em 1953; vários encontros com os Marajó do Kachpakúru entre 1948 e 1950. São, com certeza, idênticos aos Pianokotó.

64. Maráwaná

a) Maruaná, Marúwana.

b) ?

c) ? (Karíb?) .

d) ?

e) Cabeceiras do rio Cachorro.

f) ?

g) ?

h) Kachúyana.

i) Dizem que são parentes próximos ("irmãos") dos Matchúkui. (Ver n. ${ }^{\circ} 65$ ).

65. Matchúkui

a) Machúkui.

b) ?

c) ? (Karíb ?) .

d) ?

e) Cabeceiras do rio Cachorro.

f) ?

g) ?

h) Kachúyana.

i) Dizem que os Matchúkui são uma tribo-irmã dos Maráwaná.

66. Mawarí
a) -
b) ?
c) Karib.
d) Parukotó-Charúma.
e) $\mathrm{Na}$ área entre as cabeceiras do Nhamundá e Mapuera.
f) ?
g) ?
h) Chawiyána; Hichkaruyána.
i) Algumas informações dos Chawiyána revelam que os Mawarí também são Faranakarú. Deve, pois, tra- tar-se de duas tribos aparentadas ou de um mesmo grupo tribal.

67. Máwayána
a) -
b) Indios Sapo (mawa $=$ sapo).
c) Karíb .
d) Parukoto-Charúma.
e) Outrora, no Nhamundá; hoje, no Moró (formador leste do Urukurína-Mapuera) e Tcharawaú (Tchô- rôáhô ou Cachorrinho), até o alto Turúnu.
f) Foram enumeradas 8 malocas.
g) Bons, porém um tanto desconfiados.
h) Faruarú, Chawiyána, Kachúyana, Charúma, Tiriyó . 
i) São conhecidos pelos seus grandes arcos. Seu nome não passa de apelido. Contam que são homens pernaltas, de ventre volumoso "semelhante a um sapo morto, esticado" e que chegam a atingir 2 metros de altura.

68. Mêk. yana
a)
b) Indios Macaco Prego (Mêku = macaco prego).
c) ?
d) ?
e) No Kotonúru.
f) ?
g) Bravios.
h) Kachúyana.
i) Talvez ainda uma tribo selvagem de cultura marginal.

69. Mêrêwá
b) ?
c) ? (Karíb ?).
d) ?
e) No igarapé Kiremakwá, nos afluentes da margem
f) ? esquerda do alto Cachorro.
g) Dizem que são bons e amigos.
h) Kachúyana.
i) A antiga geração dos Kachúyana manteve relações com os Mêrêwá; hoje, êste contacto já não existe.

70. Mêrêyó
a) - (Emerillon).
b) ?
c) Tupí.
d) ?
e) Na região do Itani; também foram citados no Arawá.
f) Poucas malocas.
g) Bons e muito pacíficos.
h) Prôuyana, Okômoyana, Aramihh.tchó.
i) Mêrêyó é a designação das tribos Tiriyó para os Emerillon. Outrora as relações entre êles eram mais estreitas, quando os grupos Tiriyó ainda habitavam as regiôes do Itani. O nome Emerillon originou-se provàvelmente do indígena Mêrêyó.

71. Mohéyana
a) -
b) indios Taperebá (mohé = taperebá).
c) ?
d) ?
e) Entre os rios Acapu e Erepecuru.
f) ? 

g) Ferozes.
h) Kachúyana.
i) Ver VI, n." 19 .

72. Mureyána
a) -
b) ?
c) ?
d) ?
e) Na região intermediária entre Paru de Leste e Mae- curu, mais ou menos entre 1 grau de latitude sul e o equador.
f) ?
g) Ao que parece, ainda selvagens.
h) Aparaí, Wáyana.
i) Sempre citados juntamente com os Kurúmuyána, sem indicações específicas. Dizem os Aparaí-Wáyana que ainda foram vistos índios bravios nas cabeceiras do Mariussú, Kapukú e Umaratiá. Talvez se trate dês- ses indios.

73. Nêrêyó

a) Nêrêyána

b) Indios Vampiro (Tiriyó: nêrê $=$ morcêgo, vampiro).

c) ?

d) ?

e) Nas regiões do Panamá e Trombetas.

f) ?

g) Dizem que são antropófagos.

h) Tiriyó, Prêuyana, Okômoyana.

i) Provàvelmente idênticos aos Rêrêyána dos Kachú yana (ver n." 99), porque as referências muito se asmelham.

74. Okoimoyána

a) Literalmente: Indios Cobra Grande ou fndios Anaconda. E' a designação dos índios do Nhamundá para o grupo Tunayána e Charumá da região do Turúnu. Contam que os antigos Okoimoyána dormiam debaixo dágua (Ver n. ${ }^{\circ} 122$, i).

73. Okômoyána
a) -
b) Indios Vespa (okômo = caba, vespa).
c) Karíb.
d) Pianokotó-Tiriyó.
e) O antigo centro do povoamento achava-se no Ma- rawini, afluente da margem direita do Chipariwini; hoje em dia, os remanescentes estão espalhados en- tre os Tiriyó.
f) 6 ou 8 individuos.
g) Muito pacíficos e pacatos. 
h) Tiriyó: Okômoyána, Prôuyana.

i) São uma subtribo dos Tiriyó que ainda se subdivide nos Okômoyana pròpriamente ditos, nos Warípi e nos Maipurídjana. O número de indivíduos (f) refere-se aos Okômoyana autênticos. Incluindo-se os demais subgrupos, têm-se aproximadamente a cifra de 50-60 almas. Segundo as informações dos Prôuyana e Okômoyána, êstes últimos foram extintos há 2 ou 3 decênios pelos Pianokotó, provàvelmente pela tribo Kúkuyana $\left(n .^{\circ} 56\right)$.

76. Opúruí
a) Upuruí.
b) ?
c) Karíb.
d) Urukuyána.
e) No alto Paru de Leste.
f) Sòmente 2 pequenas malocas.
g) Agradáveis e pacíficos.
h) Wáyana, Aparaí, Opuruí.
i) Visitados em 1955. Pouco a pouco são assimilados pelos Wáyana. Existem apenas 3 famílias.

77. Ororikó
a) -
b) Indios Andorinha.
c) ? (Karíb ?).
d) ?
e) Nas cabeceiras do Cachorrinho.
f) ?
g) ?
h) Kachúyana.
i) Possivelmente, ainda uma tribo bravia. Não per- tencem, porém, ao grupo Warikyana. Ororikó é uma espécie de andorinha; tchurutá é outra. Se os Ororikó são os mesmos Tchurutáyana do alto Kotó- núru, não se sabe.

78. Pachkiyána
a) -
b) Indios Cutia (pachki = cutia).
c) Karíb.
d) Urukuyána.
e) Entre o Paru de Leste, o Maecuru e os campos do Erepecuru, até as cabeceiras do Achiki e Tapikurú, além do Chitaré.
f) Dizem que são númerosos.
g) Selvagens, perversos, audazes.
h) Aparaí, Wáyana.
i) Ver VI, n. 20 .

79. Pãkufádjana

a) 
b) ? (Tiriyó: pãkufa = tapioca) .

c) Karíb.

d) Parukotó-Charúma .

e) Na região do Turúnu.

f) ?

g) Ao que parece, bons e pacificos.

h) Tiriyó, Prôuyana, Marah.tchó, Charúma.

i) São mencionados, já em 1727, por Frei Francisco de São Marcos, como aldeia de "Pakepha".

80. Parik.yána

a) -

b) Indios de Parikurú.

c) Karíb.

d) ?

e) ? (Disseram: num afluente do Trombetas).

f) ?

g) ?

h) Kachúyana.

i) A existência dessa tribo não é muito certa. E' pos. sivel que Parik.yána seja = Warik. yána, assim como Paríkuru talvez seja = Aríkuru, Waríkuru ou Amazonas. A posição dêsse nome tribal é bastante obscura.

81. Parukotó

Este têrmo é quase sempre usado como nome coletivo para as tribos do Mapuera. Os Parukotó formam, iuntamente com os grupos do Turúnu e os Wabui do Nhamundá, um grupo dialetal uniforme: os Parukotó-Charúma. Todavia, parece que também existe uma tribo autônoma com êste nome. Segundo indicações dos Kachúyana, os antigos Parukotó ou Parikotó emigraram do Paríkuru. Outrora o nome do Mapuera parece ter sido Paru ou Faru. Em antigos mapas ainda se encontra designado como "rio de Faro". Essa designação "Faro" é, com certeza, uma corrutela do indígena "Paru" e não tem relaça alguma com o nome da cidade de Faro que fica no Nhamundá. Como aconteceu a muitas outras antigas missões no tempo da secularização das Missões por Pombal, também à antiga Missão do Nhamundá foi dado o nome de cidade portuguêsa: Faro. Os Farukoto, Parukotó, seriam, portanto, o "Povo do Paru, habitantes do rio Faru", que hoje é o Mapuera.

82. Parukotó

a) Parokotó, Parikotó, Parëkotó, Parikuatô, Parukwatô, Farukwatô, Farukotô; errôneamente são cognominados "Pianokotó do Mapuera".

b) Indios do Paru, isto é, do Mapuera.

c) Karíb.

d) Parukotó-Charúma. 
e) A oeste do Trombetas, espalhados desde o TurúnuCachorro, através do Mapuera até o Nhamundá-Jatapu.

f) Como grupo coletivo ainda bastante numerosos.

g) Em geral bons, amáveis e pacíficos.

h) Kachúyana, Charúma, Faruarú, Katuêma, Chawiyána, Hichkaruyána.

i) Um grupo isolado parece morar no Pokurkúru, afluen. te da margem esquerda do alto rio Cachorro. Vários grupos Parukotó foram visitados entre 1949 e 1955.

83. Patagádjana

a) -

b) ?

c) Karíb

d) Parukotó-Charúma.

e) Na região do Turúnu.

f) ?

g) Ao que parece, são bons.

h) Tiriyó, Charúma; Aparaí, Wáyana.

i) São conhecidos pelos Aparai e Wáyana como "gente que dorme debaixo dágua", e são considerados parentes dos Tunayána, dos quais se diz o mesmo. Entre as tribos do Paru, os Patagádjana são tidos como ora bons, ora temíveis .

84. Pawiyána

a) Pawichi, Pawitchi, Pauchí (Pauxi).

b) Indios Mutum (pawichi = muium).

c) Karíb.

d) Warikyana.

e) Outrora, na atual óbidos e na região da foz do rio Trombetas; hoje, existem somente pequenos grupos remanescentes no Erepecuru, nos afluentes Kuáte e Água Fria.

f) Sòmente 2 ou 3 malocas.

g) Pacíficos, embora bastante desconfiados.

h) Kachúyana.

i) São os restos dos "Pauxís" do tempo colonial. Ma dame Coudreau encontrou-se com êles nas proximidades de Água Fria (Erepecuru), onde moram até hoje. Vez por outra, aparecem, principalmente, na Cachoeira do Mel. Segundo narram os Kachúyana, os Pawichi emigraram de Pauxis $=$ óbidos. Ainda hoje a cidade de óbidos é chamada por êles: Pawidzetpó $=$ Pauxis Velho, e Oriximiná $=$ Pawichi. Històricamente, consta que, em 1747, os indios Pauxís se revoltaram contra os seus opressores portuguêses e, após massacrá-los, tomaram o rumo do Trombetas.

85. Puchúma
a) -
b) ?
c) ? 

d) ?
e) Nas cabeceiras do Jatapu-Uatumã.
f) Bravios, belicosos .
g) Chawiyána.
h) Ver VI, n. 21.

86. Pianoí
a) Pianaí.
b) Indios Gavião Real (piano, piana = harpya, gavião real) .
d) Pianokotó-Tiriyó.
e) Em todo o Chitaré, com exceção de sua foz; uma parte também no igarapé ou rio Watumiríki.
f) Ao que consta, muito numerosos.
g) Considerados selvagens pelas tribos do Paru; os Ti- riyó dizem: "pikíme óide $=u m$ pouquinho bravos".
h) Tiriyó, especialmente Aramihh.tchó; Aparaí, Wayána.
i) Ver VI, n. 22 .

87. Pianoisí

a) Pianosirí.

b) Indios Gavião Real (piano = harpya, gavião real).

c) Karíb.

d) Pianokotó-Tiriyó.

e) A oeste do Paru de Leste, em tôrla a zona do Chitaré.

f) ?

g) Bravios, selvagens, audazes.

h) Aparaí, Wáyana.

i) Com tôda a probabilidade são os mesmos Pianoí ou um subgrupo dêles. (Ver n. ${ }^{\circ} 86$ e VI, n. $\left.{ }^{\circ} 22\right)$.

88. Pianóika

a) Pianóikë.

b) Provàvelmente "Pequenos Gaviões".

c) Karíb.

d) Segundo as informações do Marah.tchó, são Tiriyó: segundo os Prôuyana, são Charúma.

e) No Iriyó (Iriau), afluente da margem direita do Panamá .

f) 1 ou 2 malocas.

g) Agradáveis, embora um pouco desconfiados.

h) Prôuyana, Marah.tchó, Charúma .

i) Partes dêste grupo, conheci em 1953, no Panamá. Etnicamente, pareceram-me uma mistura de Charúma com Marah.tchó. (Talvez daí provenha a indicação não muito clara do item d.). Todos, porém, falavam o dialeto Marah.tchó (Tiriyó).

89. Pianokotó

a) Pianokotó, Pianokwatô, Pianakuatô; pelos Kachúyana também são chamados Prôh.no-yúmu, i. é: pais de agouro . 
b) Indios Gavião Real.

c) Karib.

d) Pianokotó-Tiriyó.

e) Zona intermediária do Panamá-Marapí-KachpakúruTrombetas. (Também foram mencionados no Makrútu (Makroetoe); porém, aí deve-se tratar de um dos grupos bravios dos Tiriyó).

f) Um total de 12 ou 15 malocas (Ver Marah.tchó, n.o 63) .

g) Têm fama de briguentos, um tanto ferozes e belicosos .

h) Kachúyana, Charúma, Tiriyó, Prôuyana, Marah.tchó.

i) A respeito da questão da identidade entre os Tiriyó e Pianakotó e os Pianokotó e Marah.tchó, respectivamente, ver texto págs. 129 130. Possuem lindas canções e são conhecidos como a tribo de trovadores indigenas. Segundo informações, antigamente uma parte dêles emigrou do Paríkuru.

90. Pianokotó do Mapuera

Ver Parukotó 82, a) e Faruarú 25, i).

91. Prêh.noma

a) Prè/noma.

b) "Parentes".

c) Karíb.

d) Warikyana.

e) Nas proximidades do Erepecuru.

f) 2 ou 3 malocas.

g) Bons.

h) Kachúyana.

i) A denominação desta tribo talvez se refira aos Woyárama e Ingarüne do Ponékuru, pois Prêh. noma (pa. rentes) indubitàvelmente não é nome de tribo, mas indica uma relação social.

92. Prêh. noma
a) Prê/noma.
b) "Parentes".
c) Karíb.
d) Warikyana.
e) No Tchôrôáhô ou rio Cachorrinho.
f) ?
g) Tidos como bons.
h) Kachúyana.
i) -

93. Prôuyana
a) -
b) Indios Flecha.
c) ?
d) ? 


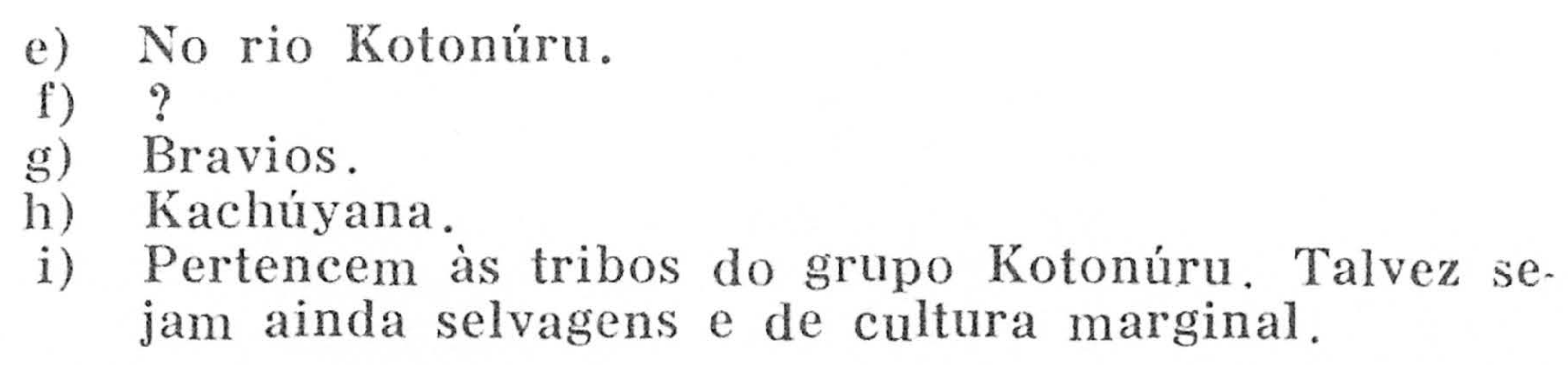

94. Prôuyana

a) Entre os Tiriyó: Prôuyana, Prôupe; entre os Warikyana: Prâuyana, Prâupe.

b) Indios Flecha (próuwe, prâuwe = flecha).

c) Karíb.

d) Pianokotó-Tiriyó .

e) Em território brasileiro: no Kumaruwíni, Marapi e alto Arakopina; em território holandês: no Tapanamí e Akalapí.

f) 7 ou 8 malocas.

g) Bons, pacíficos.

h) Prôuyana, Okômoyana, Aramihh.tchó, Aparaí, Wayana.

i) Visitados em 1950-1952. Pertencem ao povo Tiriyó e se dividem pelo menos em um subgrupo, os Rãgú (Langoe) ou Rãgú-píki. Ésses são os Prôuyana do Kumaruwíni e Kurupini. O nome Índios Flecha ou Flecheiros provém do costume de, ao sairem da maloca, sempre se munirem de um maço de flechas.

95. Plaitóno

a) -

b) Senhores de aldeia, tuxauas.

c) Karíb.

d) ?

e) Na margem direita do alto rio Cachorro.

f) 1 maloca.

g) Bons.

h) Kachúyana.

i) A antiga geração dos Kachúyana teve contacto com êsses indios. Segundo declarações expressas, Ptaitóno, nesse caso, não é nome individual ou título, mas designação de tribo.

96. Rãgú .

a) Rãgú-píki (Langoe) .

b) Segundo declaração dos Prôuyana, o nome foi tira do do ancestral da sipe, que se chamava Rãgú. Por ter sido de pequena estatura, também era chamado de Rãgú-píki $=$ pequeno Rãgú. Segundo outra versão, "píki" também quer dizer descendente ou parente mais novo. Então, Rãgú-píki significaria descendente ou, em sentido mais lato, sipe do Rãgú.

c) Karíb.

d) Pianokotó-Tiriyó.

e) No rio Kumaruwíni, no sopé da serra Awararí e no rio Kurupini. 
f) 2 malocas com mais ou menos 50-60 almas.

g) Bons, pacíficos.

h) Tiriyó, Prôuyana, Rãgú, Okômoyana .

i) Visitados em 1950 e 1952. Os Rãgú são um subgrupo dos Prouyana (Ver 94, i).

97. Rêpeworiworimó
a) -
b) ?
c) ?
d) ?
e) Na região das cabeceiras do Jatapu-Uatumã.
f) ?
g) Bravios, belicosos.
h) Chawiyána.
i) Ver VI, n. ${ }^{\circ} 23$.

98. Rêrêyána
b) Indios Vampiro (rêrê = vampiro, morcêgo).
c) ?
d) ?
e) Outrora entre o Nhamundá, o Ipitinga e o Acari.
f) Extintos (?) .
g) Bravios.
h) Chawiyána, Hichkaruyána.
i) Eram famosos antropófagos, donde sua denominação: índios Vampiro. Não devem ser confundidos com os Rêrêyána da região do Kachpakúru. São conside- rados extintos, mas os Chawiyána não estão bem certos disso.

99. Rêrêyána
a) -
b) Indios Vampiro ou índios Morcêgo.
c) Karíb (?) .
d) ?
e) Na região do Kurátari, afluente da margem direita do Kachpakúru.
f) Poucas malocas.
g) Ora bons, ora ruins; dizem que ocasionalmente ain- da se revelam antropófagos.
h) Kachuyána. (ver n. ${ }^{\circ}$ 73) dos Tiriyó. São evitados pelos Kachí- yana. Existe a possibilidade de serem os Rêrêyána os mesmos Tchíkoyana que vivem na mesma regiăo e que afirmam que além dêles não há outra tribo ha- bitando o Kurátari.
i) Provàvelmente idênticos aos Nêrêyána ou Nêrêyó

100. Sâkáka
a) Sokáka.
b) ? 
c) Karíb.

d) ?

e) Outrora no Nhamundá, entre os Hichkaruyána e Chawiyána; hoje, extintos.

f) (Extintos).

g) Consta que eram bons e pacificos.

h) Hichkaruyána.

i) O último Sâkáka morreu por volta de 1947-1948. Segundo a tradição indígena, os Sâkáka vieram do Amazonas e se cruzaram, depois, com os Hichkaruyána e Chawiyána. Desde os tempos coloniais sabe-se da existência dos Sâkáka na ilha de Marajó.

101. Seribá
a) Seribaimë, Seribá-imó.
b) ?
c) ?
d) ?
e) Outrora entre o Nhamundá e o Jatapu.
f) Extintos .
g) Belicosos, perversos.
g) Chawiyána, Hichkaruyána.
i) -

102. Taripiyó
a) -
b) Indios Macaco Prego (expressão Tiriyó: tarípi =
c) ?
d) ?
e) No sopé da serra Tumucumaque, no rio Akuritabe, afluente da margem direita do Paru de Oeste, entre Kurupíni e Paru.
f) Ao que parece, várias malocas pequenas.
g) Bravios.
h) Tiriyó: Prôuyana, Aramihh.tchó, Aramagotó.
i) Ver VI, n. ${ }^{\circ} 24$.

103. Tarudji
a) Ver Wayárama n. ${ }^{\circ} 136$, i.

104. Tchágoyána

a) Tchákoyána, Chákoyana, Chágoyana.

b) Indios Saracura (têrmo Kachúyana: Tchágo = saracura).

c) ?

d) ?

e) Entre os rios Acapu e Erepecuru.

f) ?

g) Bravios.

h) Kachúyana.

i) Ver VI, n. ${ }^{\circ} 25$. 
105. Tcharáumare
a) Charáumare.
b) ?
c) Karíb
d) Parukotó-Charúma.
e) No alto Turúnu.
f) ?
g) Bons, agradáveis.
h) Kachúyana.
i) Dizem os informantes que são vizinhos dos Charúma.

106. Tcháwiyana
a) Cháwiyána.
b) ?
c) Karíb.
d) Parukotó-Charúma.
e) Do alto Nhamundá até o Jatapu.
f) Por volta de 1940 ainda possuiam 11 malocas com 300 350 almas; em 1955 sòmente 4 ou 5 malocas com, aproximadamente, 150 almas.
g) Muito bons e pacíficos.
h) Chawiyána, Hichkaruyána.
i) Visitados em 1951 e 1955. Outrora, eram inimigos dos Hichkaruyána. Houve freqüentes guerras entre as duas tribos. Hoje, porém, vivem em boa paz e se tornaram aparentadas pelo casamento.

107. Tchiháyana
a) -
b) Indios Arraia (têrmo Kachúyana: tchihá = arraia).
c) ? (Karíb ?).
d) ?
e) No rio Kotonúru.
f) ?
g) Bravios, maus.
h) Kachúyana.
i) Talvez uma tribo selvagem de cultura marginal.

108. Tchêrêú
a) Djêrêú, Chêrêú, Serêú; também são denominados Kayáparí.
b) ?
c) Karíb.
d) Parukotó-Charúma.
e) Na região do Turúnu, até o rio Cachorro.
f) ?
g) Um tanto bravios e belicosos e, por isso, em parte temidos.
h) Tiriyó, Charúma, Kachúyana, Aparaí, Wáyana.
i) São descritos como tendo constituicão robusta, com 2 metros de altura; dizem que possuem arcos muito grandes. As tribos do Paru de Leste conhecem-nos


através da tradição. São temidos por elas, porque são tidos como bravios. Segundo os Kachúyana, não pertencem, com tôda certeza, ao grupo dos Waíkyana. Os Charúma têm contacto com êles e afirmam que pertencem ao seu grupo, falando também o Charúma. Os Chêrêú são conhecidos por todos os grupos Karíb, embora, as mais das vêzes, só por tradição e de nome. Já em 1727, Frei Francisco de São Marcos mencionava os "Sereu" como um dos povos mais belicosos do Trombetas. Segundo èle, pareciam ocupar uma posição um tanto singular. São sempre designados como inimigos do Parukuató. Notável é a sua esquisita maneira de saudar, que é uma variante da chamada "saudação hostil". A informação dos Kachúyana diz: "Quando alguém chega à sua maloca, imediatamente pegam o arco e a flecha, tomam posição, apontam para os visitantes e fingem que vão matá-los. Estes devem suportar a prova e não demonstrar mêdo, pois é apenas uma cerimônia; na realidade, não matam. Se o visitante, porém, tem mêdo e foge, então, êles pensam que tenha vindo com más intenções e... chovem flechas".

109. Tchikaridjana

a) Chikaríyana, Chikarëyana.

b) Indios Tiãcuã (Chikarë = pássaro tiãcuã).

c) Karíb.

d) Waríkyana.

e) No Panamá e Trombetas.

f) ?

g) Mais ou menos bons e pacíficos.

h) Tiriyó, Prôuyana, Okômoyana, Aparaí, Wáyana.

i) Provàvelmente idênticos aos Ingarüne e Wayárama. Visitados em 1953. O nome "Tchikaridjana" é também a designação que as tribos a leste do Trombetas dão aos Ingarüne em sentido mais amplo, quer dizer, a todo o grupo Waríkyana.

110. Tchíkoyána

a) Chikoyana.

b) ?

c) ?

d) ?

e) Na zona intermediária do Panamá e Marapi; com certeza no Kurátarí, afluente da margem direita do alto Kachpakúru.

f) No Kurátarí 4 malocas.

g) Nem bons, nem maus.

h) Tiriyó, Marah.tchó, Aramihh.tchó, Wáyana, Aparaí, Tchíkoyána.

i) A classificação dessa tribo ainda é bastante incerta. Uns dizem que são Charúma; outros, que são Tiri- 
yó, ou Marah.tchó. Em 1953, encontrei-me com uma familia Tchíkoyana, no Panamá. Estavam ali, a fim de realizar permutas de objetos com os Marah.tchó e falaram também o dialeto dêles. Todavia, quero crer que não era êsse o seu dialeto próprio. Os seus elementos culturais eram em parte Karíb; as suas flechas, porém, tipicamente tupí. Dêles recebi ainda a indicação da sua área de residência e número de malocas. Afirmaram-me, outrossim, que não existe outra tribo vivendo no Kurátarí. Será que êles se identificam com os Rêrêyána do Kurátarí? (Ver n. 99). Os Tchíkoyána são conhecidos principalmente pelas tribos do leste do Trombetas.

111. Tchôrôáyana

Também, Tchôrôwáyana. E' nome coletivo e significa literalmente: "Moradores do Tchôróáhô ou Chôrôwáho" (rio Cachorrinho) e abrange todos os indios dêsse rio, tanto Waríkyana como Parukotó-Katuêma. Com índios Tchôrôáyana dêsse último grupo, tive um encontro em 1949. Eram agradáveis e prestativos.

112. Tchôrôáyana

a) Chôrôáyana, Chôrôwáyana.

b) "Moradores do Tchôrôáhô (Tchôrôwáho)" ou rio Cachorrinho .

c) Karíb.

d) Parukotó-Charúma

e) Na altura equatorial do Tchôrôáhô e do Mapuera.

f) 3 ou 4 malocas.

g) Bons, pacíficos e comunicativos.

h) Chôrôáyana.

i) Encontrei-me com êles no Mapuera, em 1949. Pertencem ao grupo dos Katuêma do Mapuera (Ver n. 48, i) .

113. Tchurmotá
a) Churmotá.
b) ?
c) ?
d) ?
e) Nas cabeceiras do rio Cachorrinho.
f) ?
g) ?
h) Kachúyana.
i) Possivelmente seja uma tribo ainda bravia. Contu- do, não pertencem ao grupo Waríkyana.

114. Tehurutáyana
a) Churutáyana.
b) Indios Andorinha (tchuruta $=$ andorinha).
c) ?
d) ? 
e) No rio Kotonúru.

f) ?

g) Bravios.

h) Kachúyana.

i) Talvez uma tribo selvagem e, possivelmente, a mesma Oririkó (Ver n. ${ }^{\circ} 77$ ). As referências (nome, área de residência, caráter) são mais ou menos idênticas. Fala contra esta vaga possibilidade de identidade o fato de que os informantes sôbre as duas tribos (Ororikó e Tchurutáyana) eram os mesmos homens Kachúyana que sempre as diferenciaram.

115. Tiriyó

Subtribos ou subgrupos dos Tiriyó:

1. Arámayana; Aramagóto.

2. Aramihh.tchó; Aramisó.

3. Arímihotó; Arímiyána.

4. Marah.tchó (Pianokotó).

5. Okômoyana:

a) Okômoyana.

b) Maipurídjana.

c) Warípi .

6. Prôuyana; Prôupe:

a) Prôuyana.

b) Rãgú; Rãgú-píki.

Somam-se a êsses ainda alguns grupos Tiriyó bravios:

1. Akuriyó.

2. Kúkuyána.

3. Pianoi e Pianosirí.

4. Tiriyómetésē.

5. Wáma.

6. Wayarikuré (Oyarikulets).

116. Tiriyó.

a) -

b) Provàvelmente: fndios Borduna, ou seja, "indios que matam com bordunas".

c) Karíb.

d) Pianokotó-Tiriyó .

e) No recôncavo da serra Tumucumaque e zonas adjacentes; nas cabeceiras dos rios Panamá, Marapí, Kucharé, Chipariwini, Paru de Oeste, Paru de Les te (Okômôkê), Tapananí, Parúma, Akalapí, Kuruní, Kamáni etc.

f) Mais de 30 malocas com 1.000 a 1.200 almas, excetuando as tribos bravias.

g) Em geral, bons e pacíficos; os grupos bravios são considerados perigosos.

h) Todos os grupos Tiriyó; Kachúyana, Charúma, Aparaí, Wáyana. 
i) E' nome coletivo de um conjunto de tribos que se dividem aproximadamente em seis grupos mais ou menos pacíficos e seis outros ainda bravios (Ver n. ${ }^{\circ}$ 115). Visitei todos os grupos "pacíficos" nos anos de $1950,1952,1953$ e 1955.

117. Tiriyómetésē
a) Tiriyómetésem.
b) ?
c) Karib
d) Pianokotó-Tiriyó.
e) No Kuruwini, afluente do Aritawini (Itani).
f) ?
g) Bravios.
h) Tiriyó, Aramihh .tchó.
i) Ver VI, n. ${ }^{\circ} 27$.

118. Tóto
a) -
b) Primitivamente: homens, gente; mas também: ini- migos.
c) ?
d) ?
e) Entre os rios Jatapu e Uatumã.
f) ?
g) Belicosos, hostis.
h) Chawiyána.
i) Ver VI, n. ${ }^{\circ} 27$.

119. Totó-imó

Nome coletivo. Sinônimo de "Katuêma bravos", que moram entre o Mapuera e o Nhamundá (Ver VI, n.. 28).

120. Totókumu

Nome coletivo das tribos do Acari, principalmente os Chiriwiyana e Kumiyána. Também são chamados "Katuêma mansos". Totókumu significa: homens, gente e, em sentido mais amplo, parentes. Outrora eram tribos bravias, mas hoje já estão aculturadas às outras tribos Karíb e aparentadas pelo casamento com os Chawiyána. Os Totókumu pertencem todos ao grupo Parukotó da família Karíb.

121. Totóró
a)
b) Homens, gente (Totó $=$ homem; -ró $=$ sufixo que substitui o nosso verbo auxiliar: ser).
c) Karíb.
d) ?
e) Na margem esquerda do alto rio Cachorro.
f) ?
g) ?
h) Kachúyana. 
i) A geração antiga dos Kachúyana manteve, por algum tempo, contacto com êles.

122. Tunayána

a) -

b) Indios do rio; Homens da água (tuna = rio, água).

c) Karíb.

d) Parukotó-Charúma.

e) No Turúnu, principalmente no seu afluente da margem esquerda, o Wehánama.

f) Incerto; várias malocas.

g) Maiș ou menos pacíficos.

h) Kachúyana, Charúma, Marah.tchó, Tiriyó.

i) São também chamados, pelas tribos do Nhamundá, de Okóimoyana, isto é: "fndios Colra Grande" (Ver n. ${ }^{\circ}$ 74) . Consta que seus antepassados dormiam debaixo dágua .

123. Urukuyána

a) Entre os Tiriyó: Arukuyána; na Guiana Francesa: Rucuyennes.

b) Provàvelmente: f́ndios do rio Beiju ou Tribos do Ama. zonas.

c) Karíb.

d) Urukuyána.

e) Rios Paru de Leste, Jari, Itani e Parúma.

f) Um total aproximado de 28 a 30 malocas, com mais ou menos 400 almas.

g) Em geral, bons e pacíficos; um tanto astutos e tendentes ao roubo; extremamente inclinados ao comércio.

h) Aparaí, Wáyana, Opuruí, Tiriyó.

i) Visitados em 1955, no Paru de Leste. Urukuyána é o nome coletivo dêste grupo, e foi adotado por êles mesmos. Divide-se em Wáyana (Ver n. ${ }^{\circ} 135$ ) ou Urukuyána pròpriamente ditos, Opuruí (Ver n. ${ }^{\circ}$ 76) e Pachkiyána (Ver n. ${ }^{\circ}$ 78).

124. Urumamán.yana

a) -

b) Indios do Lugar dos Patos. (Têrmo Kachúyana: urumá $=$ pato; mána $=$ lugar .

c) Karíb.

d) Waríkyana.

e) Outrora no rio Cachorro; hoje em dia, desaparecidos.

f) ?

g) ?

h) Kachúyana.

i) E' um grupo Kachúyana que há várias gerações emigrou do rio Cachorro e, desde então, desapareceu. Dizem os Kachúyana que os avistaram em 1948, no interior do Travá ('Trombetas), no igarapé Worah.tchá-yáukuru. Seu nome se deriva do último lu- 
gar de sua moradia, no rio Cachorro: Uruma-máne, isto é, "lugar dos patos".

125. Wabuí

Nome coletivo das tribos da mesma lingua, do Nhamundá de hoje e de outros tempos. Individualmente são denominados: Hichkaruyána, Chawiyána, Kamáreyána (Warí) etc. Em parte, também são incluíldos os Totókumu da região intermediária do Mapuera-Nhamundá: os Chiríwiyana e os Kumiyána. O nome se deriva dos Babuí, 'Wabuí, Uabuí, Abuí, que outrora viviam no Trombetas, abaixo das cachoeiras, na zona dos atuais lagos Abuí e Abuizinho. Os Babuí foram transferidos para a Missão do Nhamundá (Tauacuera-Faro) por Frei Francisco de São Marcos, em 1725. Parece que falavam um dialeto Parukotó.

126. Waihayána
a) -
b) Indios Cacête (têrmo Kachúyana: waihá = cacête
c) ?
d) ?
e) Entre os rios Acapu e Erepecuru.
f) ?
g) Bravios.
h) Kachúyana.
i) Ver VI, n. ${ }^{\circ} 29$.

127. Waiwáiyi
a) Wayawái, Woyawái, Wayëwái.
b) ?
c) Karíb.
d) Parukotó-Charúma.
e) Outrora também no Nhamundá; hoje, nas cabeceiras do Kumúnu e na Guiana Inglêsa.
f) Pouco numerosos na região do Mapuera.
g) Bons, mas um tanto briguentos.
h) Faruarú, Chawiyána, Hichkaruyána.
i) Entre os Faruarú, êles não são muito benquistos, rei-
nando entre êles um ambiente de mútua desconfiança.

128. Wáma
a) Wáma.
b) ?
c) Karíb.
d) Pianokotó-Tiriyó .
e) Principalmente nos igarapés afluentes do Urumari (Oelemari)
f) ?
g) Em geral, considerados bravios.
h) Tiriyó, Prôuyana, Okômôyana, Aramihh.tchó, Arimi- hotó.
i) Ver $\mathrm{VI}, \mathrm{n} \cdot{ }^{\circ} 31$. 
129. Wapichiyána
a) Wapichiána, Wapichána.
b) ?
c) Aruák.
d) -
e) Cabeceiras do Tawini, estendendo-se para dentro da Guiana Inglêsa e também para o Rio Branco.
f) Em número muito reduzido no teritório paraense.
g) Bons, agradáveis .
h) Faruarú.
i) Encontrei-me com alguns dêles em 1949, nas malocas dos Faruarú, dos quais são amigos. Diz-se que em parte já são "civinizadec" "zsam roupa e corte mo- derno de cabelo. Us que vi, porém, não eram dêste tipo; apresentavam-se ainda à maneira indígena.

130. Wari
a) -
b) ?
c) Karíb.
d) Provàvelmente Parukotó-Charúma.
e) Outrora na região das cachoeiras do Nhamundá.
f) Extintos.
g) Eram muito belicosos .
h) Chawiyána, Hichkaruyána.
i) Ver VI, n. ${ }^{\circ} 31$.

131. Waríkyana
a) Waríkyana, Woríkyana, Waríkiéna, Arikiéna, Ariké- na, Aríkyana, (também Parikyana?) .
b) Indios do rio Beiju? Tribos do Amazonas.
c) Karíb.
d) Waríkyana.
e) Outrora no Amazonas e na foz do Trombetas; mais tarde no médio e alto Trombetas; hoje, extintos.
f) ?
g) Um tanto belicosos.
h) Kachúyana.
i) Trata-se dos antepassados dos atuais grupos Kuchú- yana, que emigraram do Amazonas. Nos velhos do- cumentos, êles são chamados Arikéna ou Arikiéna. Foi-me apresentado como último sobrevivente do ti- po dos "antigos", um homem com o apelido de "Ka- raíwa - o Branco". Por êle foi-me descrito o tipo dos antigos, que devem ter sido de tez clara, quase branca. "Nós somos muito mais escuros do que os antigos", disseram os Kachúyana. Referiram ainda que a côr do seu cabelo era entre castanho escuro e castanho-claro e levemente ondulado; os olhos, cla- ros, azuis. "O cabelo dêles não era assim prêto e liso, e duro como o nosso", diz outro comentário dos Kachúyana. Segundo algumas informações, os an- tigos Warikyana falavam essencialmente o dialeto 
dos atuais Kachúyana; segundo outras, porém, sua língua era diferente da atual. Isto é o que parece mais aceitável, pois o atual dialeto dos Kachúyana revela evidente influência Charúma (Tunayána?). Por outro lado, encontram-se muitos têrmos da antiga língua, que ainda é conhecida parcialmente, nos dialetos dos Aparaí e Galibí (Kalína). (Os Ingarüne teriam sido, então, Kalína?).

132. Warípi
a)
c) Karíb
d) Pianokotó-Tiriyó.
e) Na região do Chipariwíni, Ápi-égu, Kuruní (Suri- name).
f) Poucos indivíduos.
g) Bons e pacíficos.
h) Tiriyó, Prôuyana, Okômôyana.
i) São um subgrupo dos Okômôyana, que pertencem ao
povo Tiriyó. Os Warípi moram quase sempre jun-
to com outros grupos, especialmente com os Prôyana.

133. Wár.yana
a) War yëna, Wariyána, Wariána, Waríana.
b) ?
c) Provàvelmente Karíb.
d) ?
e) No alto Erepecuru-Marapi
f) ?
g) ?
h) Kachúyana.
i) Talvez se trate dos Waripi (Ver n. ${ }^{\circ} 132$ ); o sufixo -pi, -pe emprega-se, às vêzes, em lugar de -yana, p. ex., Prôupë - Prôuyana.

134. Wayampí
a) Oyampí, Ayampí.
b) ?
c) Tupí.
d) -
e) Entre o Jari e o Oiapoque.
f) ? (Certamente várias malocas).
g) Pacíficos.
h) Aparaí, Wáyana.
i) Vêm até o Jari e Paru de Leste, a fim de negociar.

135. Wáyana
a) Áyana, óyana, óiyana.
b) ?
c) Karíb.
d) Urukuyána. 
e) Rio Parủma (Tapanani?), Itani, Jari e Paru de Leste.

f) 25 ou 28 malocas, com mais ou menos 400 almas.

g) Bons, agradáveis, um pouco tendentes ao roubo e muito inclinados ao comércio.

h) Wáyana, Aparai, Aramihh.tchó, Prôuyana, Arimihotó, Okômôyana.

i) Mantêm relações amistosas com os Tiriyó e Aparaí. Pertencem ao grupo Urukuyána. Visitados no Paru de Leste, em 1955. Ao que parece, pertence a êles ainda um grupo selvagem, os Páchkiyana, dos quais explicitamente se diz que são Wáyana bravios.

136. Wayárama
a) Wâyárama, Woyárama.
b) ?
c) Karib.
d) Warikyana.
e) No alto Trombetas, Panamá, Ponékuru.
f) Pouco numerosos, no máximo 2 ou 3 malocas.
g) Bastante bons, mas um tanto briguentos.
h) Kachúyana.
i) Tribo intimamente aparentada com os Ingarüne. Ao que parece, formam dois grupos: Tarúdii (Ver n. ${ }^{\circ}$ 103) e Kuí (Ver n. $\left.{ }^{\circ} 55\right)$. Essas duas denominaçóes também podem ser nomes de dois tuxauas. As res- pectivas informações são equívocas.

137. Wayarikuré

a) Entre os Wáyana e Aparaí: Wayarikuré; entre os Ara. mihh.tchó: Oyarikuré; entre os Tiriyó (Prôyana, Arámayana etc.): Awayáikuri, Awaiyáikuri; na Guiana Francesa: Oyarikulets.

b) ?

c) Karib.

d) Pianokotó-Tiriyó.

e) No Matáwari (Matáware), afluente e formador da margem esquerda do Paru de Leste, e suas proximidades.

f) Várias malocas.

g) Desconfiados, bravios e belicosos.

h) Aramihh.tchó, Próyana, Wáyana, Opuruí, Aparaí.

i) Ver VI, n. ${ }^{\circ} 32$.

138. Wêyana
a) -
b) ? (Indios Breu? fndios do Tgarapé do Breu?).
c) ?
c) ?
d) ?
e) No rio Kotonúru.
f) ?
g) Bravios. 
h) Kachúyana.

i) -

139. Wóiremêyana
b) ?
c) ?
c) ?
d) ?
e) No rio Kotonúru.
f) ?
g) Bravios.
h) Kachúyana.
i) Talvez uma tribo bravia do Kotonúru.

1404 Wonawá
a) Wânawá.
b) ?
c) Karíb.
d) Parukotó-Charúma.
e) Outrora, na região da confluência do Panamá com o Trombetas; hoje, na zona do Turúnu.
f) ?
g) Bons .
h) Kachúyana, Ingarüne.
i) -

141. Worêyana
a) Entre os Tiriyó: Woridjana, Worijana; entre os Ka- chúyana: Worêyana.
b) Povo de Mulheres; indios Mulheres (Worê, worí $=$ mulher).
c) Karíb (como atestam as tradições e os mitos).
d) Ao que parece, eram Waríkyana ou aparentados com êles.
e) Outrora, na zona equatorial dos rios Trombetas, Ca- chorro, Cachorrinho e Kachpakúru até o Erepecuru e quase até à altura do Panamá; hoje, desaparecidos.
f) Extintos. Outrora, porém, muito numerosos, pois há ainda muitos lugares de moradia dos antigos Wo- rêyana.
g) ?
h) Kachúyana, Kah.yána, Tiriyó.
i) Trata-se dos arqueo-mitológicos "povos de mulhe- res", do rio Trombetas, que emigraram para o oes- te, estando hoje extintos (Amazonas?). E' duvidoso se realmente se trata de um "povo de mulheres", co- mo afirmam as tradições bastante concretas dos Ka- chúyana, ou apenas de um apelido dado a um povo extinto, de sistema matriarcal extremado, cujos re- manescentes talvez sejam os Warikyana-Kachúyana, único grupo no qual outrora reinou o matriarcado e que ainda hoje segue, em linhas gerais, um sistema 
matrilinear. Mitològicamente, os Worêyana são visíveis no céu como uma constelação de pequenas estrêlas.

142. Yaiheyána
a) -
b) Indios Anta (Parukotó:yaihe = anta).
c) ?
d) ?
e) Na zona dos campos do alto Nhamundá.
f) ?
g) Bravios.
h) Chawiyána, Hichkaruyána.
i) Ver VI, n. ${ }^{\circ} 33$.

143. Yaskuríyana

Nome coletivo que significa: "Moradores do rio Yaskuri ou Yatskurí"; é o grupo dos Kachúyana que morava nesse rio.

144. Yawáreméyana
a) -
b) ?
c) Provàvelmente Karíb.
d) ?
e) No Igarapé Aháuwachi, afluente da margem direita
f) ? do alto rio Cachorro.
g) Bons, pacíficos.
h) Kachúyana.
i) A antiga geração Kachúyana manteve contacto com êsses indios.

NOTAS

1. - O presente trabalho é uma tradução adaptada de um artigo alemão intitulado "Zur linguistisch-ethnologischen Gliederung der Indianerstämme von Nord-Pará (Brasilien) und den anliegenden Gebieten", publicado em Anthropos, Internationale Zeitschrift für Völker-und Sprachenkunde. Band 52, 1957, Posieux (Fribourg), Suiça, págs. 509 segs.

Com a presente publicação em língua portuguêsa o autor vem atender a solicitação coletiva que the foi feita por ocasião da IIIa. Reunião Brasileira de Antropologia, realizada no Recife, em fevereiro de 1958.

2. - Notas para a transcrição dos têrmos indígenas

Vogais: a-e-i-o: abertas

â-ê-ô: fechadas

Semiconsoantes :

w- como "w" no inglês, mas com um leve "u" pre. posto. 
y- como "ch" no alemão, p. ex.: "ach", "Bach", sileiro (em "yayá"), mas com um leve "i" pre' posto.

Consoantes: $b-d-g-k-m-n-p-t$ :

como no alemão, (portanto g sempre como em "gago")

s- sempre forte

z- $\quad$ sempre brando

$r$ - sempre dental

f- sempre bilabial

j- como " $\mathrm{j}$ " em português (jardim)

ch- como em português (chá)

O grupo $\mathrm{H}: \quad$ h- $\quad$ sempre bem aspirado como no alemão (Hand)

$h$ - como "ch" no alemão, p. ex.: "ach", "Bach", porém, um pouco mais brando.

hh- como "ch" no alemão, p. ex.: em "ich", "nicht", porém, um pouco mais brando.

- Stocklaut ou glottal stop (em muitos casos está em lugar de uma sílaba supressa com "h" inicial; p. ex.: o/ko por oh.ko = vem cá).

Africatas: dz-ts $\sim$ dj-tch

O acento tônico não é constante; donde certas variações na acentuação, segundo a eufonia.

3. - FREI ALBERTO KRUSE, ofm ( $\dagger$ 1956) possuia um pequeno vocabuláriọ de uma tribo do Alto Acapu (zona intermediária do Trombetas. Erepecuru). Colheu os vocábulos por intermédio de um homem que, por algum tempo, estivera em contacto com êsses indios. Segunído A. KRUSE, o material não pertence ao tronco das línguas Karíb; não sabia em que grupo lingüístico poderia ser incluido, parecendo tratar-se de língua isolada. Possivelmente seja falada por uma das três tribos bravias da região até agora conhecidas (Mohéyána, Wayhayána, Tchakoyána).

4. - Pianoisí não é senão o plural de PIANOI. Significa, portanto: os Pianoí.

O sufixo -ri (Pianosirí) é sufixo verbal auxiliar $=$ ser. A palavra Pianosiri, portanto, contém uma frase completa: "são os Pianoí". 
Seqüência dos números - ver mapa - de oeste para leste (da direita para a esquerda)

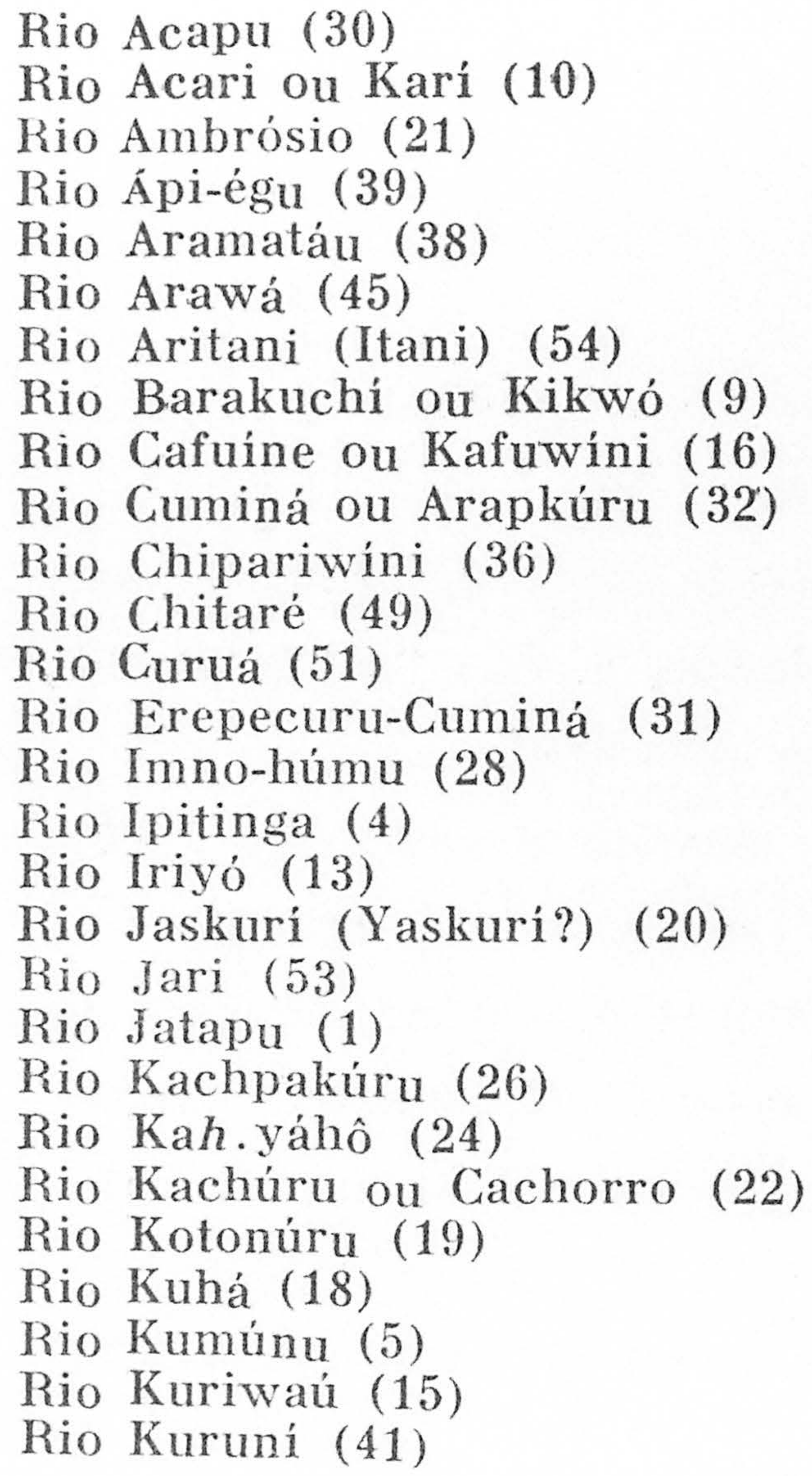

Rio Kutári (37)

Pio Maá (14)

Rio Maecuru (52)

Rio Mapuera (8)

Rio Maráka (40)

Rio Marapi (35)

Rio Marawíni (42)

Rio Matáwari (47)

Rio Nhamundá (3)

Ig. Okmawini (27)

Rio Okômokê (46)

Ig. Onomto-húmu (25)

Rio Paikuru (48)

Rio Panamá (12)

Kio Paru de Leste (50)

Rio Paru de Oeste (34)

Rio Ponékuru (29)

Rio Tapái (44)

Rio Tapanani (43)

Rio Tawini (7)

Rio Tchôrôáhô ou Cachorrinho (23)

Rio Trombetas (11)

Rio Turúnu (17)

Rio Tutúmu (6)

Rio Urucuriana (33)

Rio Wíni (2) 


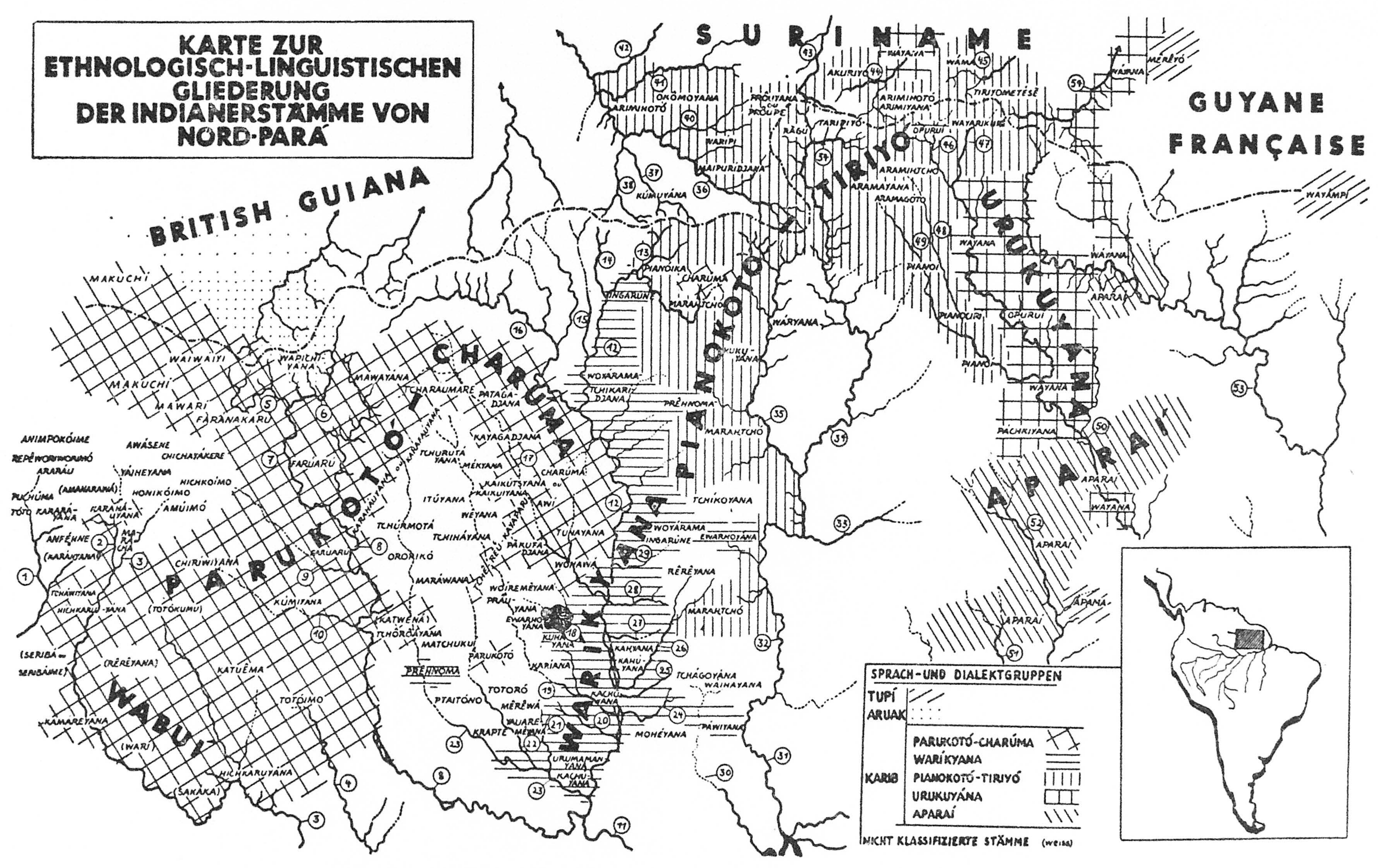

Classificação etno-lingüistica das tribos indígenas do Pará setentrional 